МИНИСТЕРСТВО ОБРАЗОВАНИЯ И НАУКИ УКРАИНЫ Харьковский национальный экономический университет имени Семена Кузнеца

\author{
А. А. Кудь, М. А. Мащенко, \\ И. С. Пипенко, И. В. Соболева
}

\title{
ПРОГНОЗИРОВАНИЕ \\ ВЛИЯНИЯ ЦИФРОВЫХ АКТИВОВ \\ НА СОЦИАЛЬНО-ЭКОНОМИЧЕСКОЕ \\ РАЗВИТИЕ ПРЕДПРИЯТИЯ
}

Методическое пособие

Харьков

"ХОГОКЗ"

2020 
УДК 338.12.017(072)

DOI 10.26697/9786177089109.2020

П 78

Рекомендовано Учёным советом

факультета экономики и права ХНЭУ им. С. Кузнеца

(протокол № 6 от 11 марта 2020 года)

Авторский коллектив:

Кудь А. А. (раздел 2), Мащенко М. А. (введение, раздел 3, выводы), Пипенко И. С. (раздел 1), Соболева И. В. (раздел 3).

\section{Рецензенты:}

Гавкалова Н. Л. - доктор экономических наук, профессор, заведующая кафедрой государственного управления, публичного администрирования и региональной экономики Харьковского национального экономического университета имени Семена Кузнеца.

Марченко О. С. - доктор экономических наук, профессор, профессор кафедры экономической теории Национального юридического университета имени Ярослава Мудрого.

\section{Прогнозирование влияния цифровых активов на}

П 78 социально-экономическое развитие предприятия: метод. пособ./Кудь А. А. и др. Харьков: ХОГОКЗ, 2020. 80 с. doi:10.26697/9786177089109.2020

В методическом пособии исследовано явление социально-экономического развития, обоснованы особенности социокультурного контекста, которые формируют понимание сущности социально-экономического развития; определено влияние современных информационных технологий, которые существенно меняют модели и способы ведения бизнеса. Исследована сущность понятия «цифровой актив» на основании этимологического анализа и прогнозирования социально-экономического развития под влиянием цифрового актива в условиях антимонополизации экономики. Определены принципы построения антимонопольного регулирования экономики в условиях цифровизации экономики. Это исследование согласовано и утверждено как научно-исследовательская работа ХНЭУ им. С. Кузнеца (договор № 649-56 от 13.12.2019 г.). Методическое пособие адресуется специалистам в сфере информационной и цифровой экономики, юристам, финансовым организациям, представителям бизнес-сообществ.

УДК 338.12.017(072)

Издание размещается в международных репозиториях и базах данных: Crossref, Google Scholar, Scilit, eKRPOCH, Kopernio и др.

\section{ISBN 978-617-7089-10-9}

(C) ХНЭУ им. С. Кузнеца, 2020

(C) Кудь А. А., Мащенко М. А., Пипенко И. С., Соболева И. В., 2020

(C) ХОГОКЗ, оформление, 2020 


\section{СОДЕРЖАНИЕ}

Перечень сокращений и условных обозначений 4

Вступление

Раздел 1. Теоретические основы социально- 6 экономического развития в современных условиях

Раздел 2. Комплекс базовых понятий феномена 28 «цифровой актив»

Раздел 3. Влияние цифровых активов на социальноэкономическое развитие и роль прогнозирования в условиях антимонополизации экономики

Выводы

Литература 


\section{Перечень сокращений и условных обозначений}

ВВП - Валовой внутренний продукт

$\mathrm{EC} \mathrm{-} \mathrm{Европейский} \mathrm{союз}$

IT - Информационные технологии

МВФ - Международный валютный фонд

МOT - Международная организация труда

ПРООН - Программа развития Организации Объединенных Наций НИИКР - Научно-исследовательские и исследовательскоконструкторские работы НТР - Научно-технические разработки США - Соединенные Штаты Америки 


\section{ВСТУПЛЕНИЕ}

Повышение уровня и качества жизни населения зависит от социально-экономического развития государства. На современном этапе социально-экономическое развитие стран мира все больше оказывается под влиянием процессов цифровизации, которые изменяют подходы к решению проблем на разных уровнях и в разных сферах жизни. Они в основном нацелены на поиск новых возможностей для повышения благосостояния и решения насущных социальных проблем: от охраны здоровья до образования и окружающей среды. Цифровые технологии, появившиеся на протяжении последнего десятилетия, помогают найти источники повышения эффективности и возможности стремительного конкурентного развития рыночных бизнес-структур. Развитие цифровой экономики в целом и цифровых технологий в частности определило появление нового понятия - «цифровой актив» - и стремительное развитие связанных с ним процессов.

В аспекте усиления и обострения проблем социальноэкономического развития национальной экономики возникает вопрос поиска результативной модели государственного управления экономики в Украине, одной из ключевых функций которой является прогнозирование. Такая проблематика является актуальной, учитывая усиление проблем монополизации национальных рынков, сворачивание малого и среднего бизнеса. Приоритетным направлением развития системы антимонопольного регулирования являются смена общей концепции такого регулирования и внедрение европейской модели антимонопольной политики. Тем не менее можно уверенно утверждать о необходимости уточнения теоретических основ системы антимонопольного регулирования и построения ее структуры с учетом функции прогнозирования в условиях цифровой экономики.

Целью работы является разработка теоретикометодологической основы, методических подходов и практических рекомендаций относительно прогнозирования влияния цифрового актива на социально-экономическое развитие предприятия. 


\section{РАЗДЕЛ 1. ТЕОРЕТИЧЕСКИЕ ОСНОВЫ СОЦИАЛЬНО-ЭКОНОМИЧЕСКОГО РАЗВИТИЯ В СОВРЕМЕННЫХ УСЛОВИЯХ}

Понимание концепции социально-экономического развития в экономике изменилось с началом возникновения самой дисциплины: от экономического роста через экономическое развитие до социально-экономического развития.

Поскольку мировая экономика изменяется так быстро, ключевые движущие силы, лежащие в основе глобальных социальноэкономических изменений, включают изменения в моделях производства и потребления, новые технологические инновации и способы ведения бизнеса, а также социальные и политические изменения.

В контексте рассмотрения данного явления важно исследовать особенности социокультурного контекста, которые формируют его понимание, а также влияние современных информационных технологий, существенно меняющих модели и способы ведения бизнеса.

Технология является ключевым фактором этих изменений; новые технологии значительно улучшили сферы производства, финансов, коммуникаций и другие, благодаря чему мир быстро интегрируется в единый рынок. Торговля и прямые зарубежные инвестиции, наряду с более широким географическим распространением увеличения доходов и возможностей, содействуют дальнейшей интеграции возрастающего количества стран в более широкий международный обмен.

В соответствии с последними данными, представленными Мировой организацией торговли, торговля и глобализация в целом принесли огромные выгоды многим странам и гражданам. Торговля позволила странам получить выгоду от специализации и экономики, чтобы производить в более эффективных масштабах. Это повысило продуктивность и доходы, стимулировало экономический рост, способствовало распространению знаний и новых технологий, а также расширило диапазон выбора, доступного для потребителей.

Глобальная торговля, потоки товаров и услуг имеют решающее значение для достижения стойкого роста в развивающихся странах. 
Наряду с торговлей возрастающие потоки капитала через национальные границы вносят значительный вклад в экономический рост и сокращение бедности. Международная мобильность и разделение труда также приводят к существенным изменениям в разделении по странам.

Множество правительств развивающихся стран в последнее время открыли свою экономику для международной торговли с помощью многосторонней торговой системы, расширения регионального сотрудничества либо в рамках программ внутренних реформ социально-экономического развития.

Несмотря на недавний глобальный экономический кризис, мировая торговля резко возросла за последнее десятилетие, увеличившись почти в три раза. Развитые страны, как и раньше, являются основными игроками в международной торговле, в то же время наблюдается возрастание доли развивающихся стран. Интеграция развивающихся стран в мировую экономику, несмотря на хорошие результаты в целом, была достаточно разнообразной. Восточная Азия продолжает доминировать в торговых потоках развивающихся стран, в то время как другие регионы сильно отстают. Китай становится все более важным торговым партнером для многих других развивающихся стран не только в Восточноазиатском регионе, но и в странах Африки (на юг от Сахары) и в Латинской Америке.

По официальным статистическим данным Министерства развития экономики, торговли и сельского хозяйства Украины мы можем проследить динамику состояния экономического развития в Украине за последний год [1].

По показателям прироста/снижения:

- промышленного производства: 0,0\% (январь-сентябрь, 2019);

- сельскохозяйственного производства: $+5,9 \%$ (январь-сентябрь, 2019);

- капитальные инвестиции: +12,3\% (январь-июнь, 2019);

- прямые зарубежные инвестиции: $+2,6 \%$ (по состоянию на 01.07.2019);

- внешняя торговля товарами (сальдо): $-5842,7$ млн долл. США (январь-август, 2019); 
- внешняя торговля товарами (экспорт): +6,9\% (январь-август, 2019);

- рынок труда (по методологии МОТ): 8,5\% (январь-июнь, 2019);

- рынок труда (оплата труда): +9,5\% (январь-сентябрь, 2019);

- потребительские цены (до декабря предыдущего года): +3,4\% (сентябрь 2019 до декабря 2018);

- потребительские цены (до предыдущего месяца): +0,7\% (сентябрь 2019 до августа 2019).

Итак, приведенный Министерством анализ экономического развития в Украине является важным, но ограниченным способом исследования социально-экономического развития государства, поскольку не учитывает социокультурный контекст, приоритеты, определенные международными учреждениями, и т. д.

Наше исследование открывает новые возможности для системного анализа этого сложного процесса в странах ЕС за последнее десятилетие и на этой основе позволит спрогнозировать тенденции развития экономики Украины с учетом взглядов международных учреждений, влияния социума на рыночные отношения, а также современных цифровых технологий на данный процесс в целом.

Рассмотрим явление социально-экономического развития более обоснованно.

Сегодня проявлением лучшего определения социальноэкономического развития и фактором, влияющим на способ понимания данного явления, являются главным образом документы международных организаций (например: агентств по развитию, Программы развития ООН (ПРООН), Продовольственной и сельскохозяйственной организации ООН, Международного валютного фонда (МВФ), Всемирного банка) и декларации стран, которые сотрудничают для достижения целей этого развития. Например, цели в отрасли развития, сформулированные в Декларации тысячелетия, предложенные ПРООН в 2000 г., включают сокращения масштабов нищеты, охрану здоровья, постоянное использование ресурсов, образование, продовольственную безопасность и благоприятное управление. Размышления о развитии больше не воспринимаются в контексте борьбы с бедностью в отстающих регионах. Такое широкое 
понимание социально-экономического развития играет важную роль. Этот поворот связан с возрастающим значением гуманизма, а также с философскими и социологическими идеями относительно равенства возможностей. Очевидно, что популярность заботы об окружающей среде и осознание роли социального капитала также являются важными факторами.

Экономический рост, который является «неизменным и природным экономическим правом», проявляется в увеличении общего объема производства, что ведет к улучшению условий жизни населения. Теория экономики дает три причины экономического роста: накопление капитала, прирост населения и технологический прогресс. Сегодняшняя дискуссия относительно определяющих факторов роста указывает на дополнительные вопросы, такие как: инвестиции в производственный капитал, инвестиции в человеческий капитал, НИИКР, открытость к торговле и доступ к развитым финансовым рынкам. Это дополняется соответствующей экономической политикой, позволяющей поддерживать инфляцию на желаемом, стабильном уровне, а также правовыми и институциональными условиями, создающими благоприятную для бизнеса среду, поощряющую старт бизнеса.

Неравномерное распределение факторов роста негативно сказывается на местной, национальной и региональной экономике. Эта ситуация отражается на неравномерном экономическом развитии, что означает разностороннее социальное развитие. Диспропорции в социально-экономическом развитии, в свою очередь, негативно влияют на эффективное использование имеющихся экономических ресурсов и признаются главным барьером для экономического развития.

Вопрос, как уменьшить отличия в социально-экономическом развитии, является предметом исследований и практического измерения концепции Европейского союза. Трансформация Европейского сообщества в Европейский союз, экономический и валютный союз, заставила принять меры для уменьшения неравенства в экономическом развитии между членами. В соответствии с Договором о Европейском союзе: «в своей деятельности Союз имеет целью устранить неравенства (...)» [2]. Это должно осуществляться политикой сплоченности, сфера 
деятельности которой (пространственная и временная) развивалась на протяжении многих лет. Ранее политика сплоченности была сосредоточена на планах и их финансировании в рамках национальной политики; со временем инвестиционный горизонт и пространственный масштаб - от внутренних инвестиций до трансграничных или региональных инвестиций (макрорегионы ЕС) были расширены [3]. Достижение цели Договора о ЕС требовало большей финансовой лояльности к регионам с более слабыми экономическими условиями. Они включали преимущественно страны Центральной и Восточной Европы, которые присоединились к ЕС в 2004, 2007 и 2013 годах. Хотя сначала сокращение неравенства ограничивалось прежде всего уменьшением разрыва между ВВП на душу населения и уровнем безработицы, изменения в приоритетах развития ЕС привели к изменениям в восприятии - теперь важным было то, какие неравенства следует уменьшить. Экономические показатели (ВВП, уровень безработицы) были оправданы при оценке Лиссабонской стратегии, которая предусматривала, что Европа станет наиболее конкурентоспособным регионом до 2010 года. Отсутствие успеха в реализации данной стратегии привело к изменениям приоритетов Политики ЕС. Новые приоритеты описаны в стратегии «Европа - 2020», которая предусматривает, что до конца второго тысячелетия 21 века Европа будет наиболее согласованной, чем когда-либо, и ее развитие будет: «...разумным путем более эффективных инвестиций в сфере образования, исследований и инноваций; стойкое, благодаря решительному продвижению к экономике с низким содержанием углерода; и инклюзивное, с сильным акцентом на создание рабочих мест и уменьшение бедности» [4]. Учитывая вышеобозначенные приоритеты развития, возникла потребность расширить набор показателей на пять направлений: (I) занятость, (II) научно-исследовательские работы, (III) изменение климата и энергетика, (IV) образование, (V) борьба с бедностью и социальным отчуждением, размеры которых составляют основу для оценки прогресса в достижении целей. В документе GDP and beyond. Measuring progress in a changing world [5], помимо дополнения экологических и социальных показателей, Европейская комиссия также предложила [5, с. 5-11]: 
1) информацию в режиме реального времени для принятия решений;

2) более точную отчетность о распределении и неравенстве;

3) разработку табло европейского устойчивого развития;

4) распространение национальных счетов на экологические и социальные вопросы.

Модифицированный подход $к$ вопросу, как измерять неравенства между регионами, также несколько изменил объем вопросов, которые охватываются политикой сплоченности. В финансовой перспективе на 2014-2020 годы большое значение уделяется, помимо безработицы, промышленности и сельского хозяйства, разногласиям в отношении: «...инноваций, уровня образования, окружающей среды и бедности» [3, с. 200]. Что необходимо для ускорения роста: эффективное использование имеющихся ресурсов и связь экономик транспортными системами и информационными технологиями. Ответом на данные вопросы является финансовый инструмент ЕC (Connecting Europe Facility $\mathrm{CEF),} \mathrm{главная} \mathrm{цель} \mathrm{которого} \mathrm{-} \mathrm{поддержка} \mathrm{экономического} \mathrm{роста,}$ повышение уровня занятости и конкурентоспособности экономики ЕС путем финансирования инфраструктурных инвестиций, осуществленных в рамках сотрудничества - относительно ЕС уровня. Проекты, которые финансируются CEF: «...заполнение отсутствующих звеньев в европейской энергетике, транспорте и цифровой основе» [6].

Экономики Центральной и Восточной Европы, присоединившиеся к Европейскому союзу последними (последние три расширения EC: 2004, 2007, 2013 гг.), отличаются от экономик предыдущих стран - членов ЕС. Это было последствием политического и экономического разделения Европы на две области после Второй мировой войны. В экономическом плане это сферы: рыночная экономика и централизованная плановая экономика. Политические и экономические преобразования, начатые в конце 1980-х, позволили некоторым странам присоединиться к Европейскому союзу. Членами ЕС (из этого региона Европы) в 2004 году были: Эстония, Латвия, Литва, Польша, Чехия, Словакия, Словения и Венгрия, в 2007 году: Болгария та Румыния, а в 2013 году - Хорватия. Отличия между так называемыми старыми и новыми 
членами ЕС проявились во всех аспектах функционирования государства: управление, экономическое, социальное, правовое, финансовое и т. Д. Слабыми сторонами постсоциалистической экономики были: неэффективные и убыточные экономические структуры, крепкие связи с советской экономикой (самый крупный, временами единственный экспортер ресурсов и импортер готовой продукции), задержка в сравнении с Западной Европой в развитии ключевых отраслей: транспорта, энергетики и связи. В 2014 году совместный отчет был подготовлен Энергетическими партнерами Центральной и Восточной Европы (CEEP) совместно с Институтом CEED при поддержке Группы LOTOS S. A. и Oil Exploitation Enterprise S. A. PERN «Friendship»: Completing Europe - From the North-South Corridor to Energy, Transportation, and Telecommunications Union [7]. В отчете представлена возможность «завершить интеграцию» Европейского союза путем создания сети энергетических, транспортных и коммуникационных связей в странах Центральной и Восточной Европы. В отчете, помимо так называемых новых членов Европейского союза, Австрия также была включена из-за стратегического расположения в предложенном инфраструктурном коридоре Север-Юг. Инициативу тесного сотрудничества между бывшими социалистическими странами впервые продвинул президент Хорватии. Началом совместных усилий для укрепления стран восточной Европы стала встреча в НьюЙорке по случаю сессии ООН осенью 2015 года. Название «Инициативы трех морей» (The Three Seas Initiative) было предложено как указание на зону, подлежащюю охвату европейские государства между Балтийским, Адриатическим и Черным морями. Хотя страны, приглашенные к Инициативе, составляют почти 43\% всех членов ЕС, они занимают меньше $30 \%$ поверхности ЕС, а их население составляет немногим более $20 \%$ населения ЕС.

Это означает, что членами Инициативы являются небольшие страны как по площади, так и по количеству населения. Как результат, отсутствие экономии в масштабах значит, что некоторые инвестиции в транспорт, энергетику и транспортирование не являются прибыльными. Тем не менее без этих инвестиций прогресс 
будет не таким быстрым, как в странах Западной Европы (кроме Австрии).

Целью Инициативы является выравнивание уровней развития экономик, для достижения которых необходимы действия для повышения связности, взаимодополняемости и, в конце концов, процветания. Энергетика, транспорт и цифровая связь были определены как ключевые сферы сотрудничества.

Модифицированный индекс социального и экономического развития (SEDI) используется для оценки уровня развития. Индекс позволяет проводить многоуровневый анализ социальноэкономического развития и состояния исследуемой экономики относительно выбранных экономик.

Показатели включали меры, связанные с разными социальноэкономическими аспектами. Их выбор был тесно связан с приоритетами, обозначенными в стратегии «Европа - 2020». Во время исследования изучено, насколько велики отличия между странами, прошедшими через политические преобразования, и так называемыми старыми членами Союза. Поскольку исследование касалось стран, которые принимают участие в «Инициативе трех морей», помимо постсоциалистических стран, была также проанализирована Австрия. Показатели SEDI были рассчитаны для всех двенадцати стран Инициативы и для всего Европейского союза. Три выбранных года, за которые рассчитывались SEDI - 2004, 2009 та 2013 гг.

В 2004 году состоялось самое большое расширение Европейского союза и его структуры начали функционировать в восьми странах Центральной и Восточной Европы. Таким образом, показатели SEDI продемонстрировали состояние этих стран в отличие от Австрии и ЕС в целом. Хотя следующее расширение состоялось в 2007 году, еще один SEDI был оценен только в 2009 году. Это был пятый полный год, когда восемь стран действовали в EC, и третий год членства Болгарии и Румынии. Кроме того, в 2009 году на экономике отразилось большинство последствий финансового кризиса, и это сказалось на годичных показателях. 2013 год был избранным годом последнего расширения ЕС до Хорватии.

На основе полученных результатов был сделан вывод, что постсоциалистические государства не только вступили в ЕС с более 
слабыми экономиками, но и не в состоянии эффективно уменьшить свои социально-экономические пробелы, несмотря на функционирование в пределах ЕС. В 2004 году самое большое значение было достигнуто для экономики всего Европейского союза, за ним - Австрии. В 2004 году только Словения и Эстония достигли уровня выше среднего показателя SEDI. Bсе другие страны имеют более низкие значения среднего показателя SEDI. Самыми значительными экономиками в 2004 году обладали Хорватия, Болгария и Румыния, которые еще не были членами ЕС в исследуемом году. В 2009 году, за исключением Словении, «новые» страны Европейского союза получили более низкие значения среднего уровня показателя SEDI. Это было последствием финансового кризиса, который особенно ощущали самые слабые экономики. В случае Австрии, Словении или всего Европейского союза показатель возрастал, это значит, что несмотря на сложные экономические условия, произошел социально-экономический рост. Экономически слабые страны сильно пострадали от экономического спада, который проявился в особенно высоких уровнях безработицы, снижении инвестиций и меньших инвестициях НИИКР. Наибольшее снижение зафиксировали Болгария на $32 \%$, Польша на 25\% и Литва, Латвия и Венгрия на 22\%. Для того чтобы увидеть, возрастали ли неравенства между странами в 2004-2009 годах, использовался индекс Джини. Оказалось, что, хотя разница в SEDI в 2004 году породила индекс Джини на уровне $\mathrm{IG}_{2004}=0,100069$, индекс Джини 2009 года увеличился до $\mathrm{IG}_{2009}=0,196556$ [8].

Существенные отличия в уровне социально-экономического развития, возникшие в 2009 году, на протяжении последующих нескольких лет не компенсировались. Хотя Европейский союз в целом немного потерял значение SEDI (9\% в сравнении с 2009 годом), и все оцененные экономики возросли, это не означает равного развития. В 2013 году экономика Австрии и средний уровень экономического развития ЕС значительно отличаются от остальных. А также среди экономик, которые трансформировались, наблюдается все большая диспропорция. Если в 2004 году всего лишь две «новые» страны имели SEDI выше среднего уровня в EC, в 2013 году уже четыре страны превышали это среднее значение (Словения, Чехия, Эстония и Латвия), а еще две (Словакия и Польша) показали всего 
лишь немного ниже. На другом конце рейтинга значения SEDI были такими же, как у Хорватии, Румынии и Болгарии. На протяжении всего исследуемого периода половина экономик увеличивала свой потенциал для решающего социально-экономического развития, учитывая темпы роста SEDI - это Австрия (68\%), EC (26\%), Латвия и Чехия (13\%), Словения (9\%) и Словакия (5,2\%). Отсутствие прогресса в достижении целей «Европа - 2020» со снижением значений SEDI было зафиксировано в Болгарии (-26\%), Хорватии $(-12 \%)$, Эстонии (-6\%), Литве и Румынии $(-5 \%)$, Венгрии $(-4 \%)$ и Польше (-1\%). Несмотря на то, что разные направления изменений были отмечены в исследованных экономиках, диапазон которых был высоким (от $68 \%$ роста SEDI до $26 \%$ в SEDI), изменения SEDI в регионе Инициативы незначительно уменьшились в сравнении с 2009 годом, хотя все еще были выше, чем в 2004 г. Индекс Джини составлял: $\mathrm{IG}_{2013}=0,16$.

Итак, страны, которые присоединились к Инициативе, сохраняют колоссальную разницу в социально-экономическом развитии, что измеряется SEDI. Австрия остается решающим лидером в своем развитии. Среди стран, которых коснулись системные преобразования, социально-экономические условия в Словении и Чехии быстрее всего изменились. Самая негативная ситуация была в балканских странах: Болгарии, Румынии и Хорватии. С одной стороны, слабое положение трех стран с самым низким SEDI может быть связано с самым коротким периодом членства в Европейском союзе. С другой стороны, это может значить также невозможность преодоления слабых сторон, которые в разной степени повлияли на все экономики под влиянием Советского Союза. Это подтверждается показателем Джини, который показывает, что во время глобального спада значительно пострадали от кризиса «новые» страны ЕС. Диверсификация экономического развития значительно углубилась. Мировое экономическое возрождение помогло некоторым экономикам (Словения, Чехия, Эстония, Латвия, Словакия и Польша), но что касается Болгарии или Румынии, изменения были почти незаметны. Отображением данной ситуации было незначительное изменение значения индекса Джини с 0,19 (в 2009 году) до 0,16 (в 2013 году). 
Таким образом, проведенный анализ свидетельствует, что у государств «Инициативы трех морей» нет надлежащего потенциала для обеспечения этих экономик более быстрым и лучшим ростом, что соответствует целям стратегии «Европа - 2020».

Рассмотрим явления социально-экономического развития в контексте рыночной экономики, в частности, с точки зрения влияния субъектов и организационных подразделений государственного сектора на процессы социально-экономического развития.

В условиях рыночной экономики социально-экономическое развитие рассматривается как результат взаимодействия организационных структур и подразделений государственного сектора, роль которых состоит в поддержке и стимулировании развития, особенно среди организаций частного сектора, отвечающих за фактический ход экономических процессов, связанных с рыночным производством товаров и услуг. Поэтому проведение исследования взаимосвязей между организациями, организационными подразделениями, входящими в состав государственного сектора, и предприятиями, работающими в реальной сфере рыночных условий, приводят к установлению фактической причинно-следственной связи, а также роли и важности конкретных групп субъектов и их влияния на ход экономических процессов в рыночных условиях. Здесь особую роль играют принципы и методы предоставления социальных услуг. В контексте данного исследования социальные услуги включают все административные меры, касающиеся социальных потребностей граждан, медицинских служб, образования, персональных социальных услуг, услуг по уходу, жилищных услуг, служб занятости и специализированных служб, а также денежных переводов для разных групп населения общества.

В современных нестабильных условиях экономических рынков, а также все более нестабильных рыночных механизмов в Европе и мире необходимо проверить как возможности, так и угрозы относительно поддержки социально-экономических процессов в условиях рыночной экономики. Важно обратить внимание на очень разнообразный спектр задач и обязанностей организационных структур и подразделений, входящих в состав государственного сектора, и предприятий, работающих в реальной сфере рыночных 
условий. Следует подчеркнуть, что инвестиционные издержки являются важнейшим фактором, непосредственно влияющим на уровень и качество предоставления государственных услуг, включая уровень и качество социальных услуг.

Однако более широкий контекст процессов развития, включая роль государственного сектора и социальных служб, нельзя не заметить, особенно в отношении проблем глобального развития, в целом обозначенных в концепции экономики развития. В соответствии с концепцией экономики развития следует искать оптимальное распределение ресурсов и поддерживать экономический рост для бедных стран, которые не всегда принимают участие в процессах глобализации и развития.

Поэтому следующая задача исследования - выявить и проанализировать текущие возможности и ограничения, возникающие в процессе финансового развития на региональном и местном уровнях, в условиях рыночной экономики стран ЕС.

Основное внимание исследования ограничивается определением роли организационных структур и подразделений государственного сектора в процессе поддержки экономического развития и предоставления социальных услуг.

В условиях рыночной экономики экономические и социальные явления могут изучаться как в макроэкономическом контексте, так и c определенной территориальной точки зрения. Аналогичная закономерность касается формы вышеуказанных отношений между субъектами государственного и частного секторов. Значительный объем влияния государственного сектора на экономику реализуется на уровне государства, действиями правительственной администрации, включая обе функции создания нормативноправовых актов на уровне исполнительной власти и ряд мер на уровне публичных вмешательств с сильной финансовой компонентой, а также контрольными функциями. При этом особое внимание следует уделять деятельности, имеющей прямое финансовое измерение, которая осуществляется за счет инвестиций, финансирующихся из государственного бюджета либо системы проектно-ориентированных субсидий, адресованных разным отраслям экономики, и которая используется для поддержки реализации определенных социальных и экономических целей, и 
особенно для поддержания процессов, связанных с предоставлением социальных услуг.

Несмотря на безусловно важную роль государственной поддержки, которую оказывают на центральном уровне, реальные тенденции социально-экономических изменений свидетельствуют о необходимости тщательного анализа проблем развития с местной точки зрения. Сущность регионального подхода к экономическим и социальным процессам заключается в выявлении потенциала развития самого региона, внешних условиях, формирующих позицию региона относительно деловой среды, а также определении компетенций и взаимосвязей между субъектами, имеющими доступ к разным экономическим ресурсам региона и формированию возможностей и форм их применения. Учитывая это, стоит указать на особую роль субъектов государственного сектора на региональном и местном уровнях.

В этой структуре местное самоуправление региона исполняет важные функции в отношении административной территории, которая подчиняется вышеуказанному правительству. Это, в частности, функции, координирующие ряд мероприятий, ориентированных на развитие, осуществляемое органами местного самоуправления регионов. С точки зрения формирования будущих социальных и экономических явлений на местном и региональном уровне, определенное внимание следует уделять инструментам стратегического управления, долгосрочным инвестиционным программам, долгосрочному финансовому управлению материальным имуществом, которое принадлежит органам местного самоуправления, как основным сферам процесса принятия решений, последствия которых имеют прямую связь - процесс повышения качества жизни жителей этой административной единицы.

Объем компетенций, а также сфера ответственности местного самоуправления могут отображаться во многих сферах административной и служебной деятельности, а также инвестиционной деятельности, что в значительной мере определяют эффективность коротко- и долгосрочного формирования условий развития. Поэтому важной задачей местного самоуправления является проведение анализа и принятие решений относительно реализации инвестиций, предложенных социальными группами 
(советами, социальными организациями и т. д.), а также учет инициатив и предложений, поданных петиционными внешними инвесторами.

Что касается инвестиций, осуществленных непосредственно органами местного самоуправления, необходимо должным образом оценить рациональность таких проектов, что может быть продемонстрировано подготовкой каждого инвестиционного проекта с точки зрения его масштаба, ссылаясь на факторы, такие как количество будущих пользователей и функции, характерные для элементов технической и социальной инфраструктуры. Одним из важнейших факторов может быть массивность инфраструктурных элементов, что часто определяет недостаточную обоснованность для осуществления инвестиционных проектов небольшого материального, а значит, финансового масштаба, как следствие навязывание необходимости реализации масштабных сложных проектов с высокими финансовыми издержками.

Роль органов местного самоуправления в контексте формирования явлений развития проявляется исполнением намеченных намерений, всесторонне описывая все сферы функционирования и особенный характер данного подраздела и одновременно сохраняя сферу компетенций, что является адекватным для государственного сектора. Современные условия рыночной экономики в значительной степени принуждают достичь определенного уровня экономической эффективности действий, которые осуществляются местными общинами. Кроме того, наряду с цивилизованным прогрессом возрастают социальные ожидания, включая как более суровые экологические требования, так и необходимость внедрения новых технологий, что порождает потребность обеспечения большего объема средств, предназначенных для строительства, обслуживания и модернизации компонентов инфраструктуры. Стремление достичь возрастания степени социальной удовлетворенности в условиях рыночной экономики в отношении государственного сектора соответствует разработке новых концепций управления, включая менеджмент, основанный на аналогии между управлениями, которые предоставляют государственные услуги, и менеджмент организации, сосредоточенный на прибыли. 
В странах ЕС, как и в любых других высокоразвитых странах, изменение способов приближения к проблеме управления субъектами и организационными подразделениями в государственном секторе, включая подразделения местного самоуправления, движется к повышению эффективности и эффективному функционированию, а также обеспечению социальными услугами. Важные изменения в сфере формирования процессов развития связаны с увеличением самостоятельности подразделений местного самоуправления и популяризацией, по крайней мере в ориентировочном плане, отношения «менеджера», который побуждает к большей активности и ответственности за выполненные задачи, включая необходимость новых, более эффективных решений стратегического планирования и прогнозирования последствий действий на будущие периоды.

Данная проблема имеет широкий социальный и экономический характер, поскольку выходит за пределы государств и регионов. Это проявляется в ряде проблем в разнообразных формах организации и функционирования государства и общества, во многих демографических проблемах и многих проблемах предоставления государственных услуг. Существует много примеров, когда эти проблемы приводили к ряду опасных напряженных ситуаций в мире. Одним из возможных решений является ссылка на концепцию экономики развития.

Что касается подразделений местного самоуправления, то важной проблемой является функция системы объединения ресурсов и финансирования разнообразных государственных задач. В данном аспекте это проблема как решений в отношении общего размера государственных средств, так и в отношении их детального использования. Это также связано с вопросами финансовой независимости местного самоуправления, а следовательно, и уровня независимости отдельных подразделений относительно органов государственной власти центрального уровня. В значительной степени независимость и финансовая стабильность местного самоуправления, а следовательно, способность обеспечить надлежащий процесс предоставления государственных услуг и возможности долгосрочного подхода в формировании развития определенной административной единицы определяются структурой 
бюджетных доходных ресурсов. В то же время стоит подчеркнуть, что основу финансовой экономии органов местного самоуправления составляет бюджет, являющийся децентрализованным планом доходов и расходов.

Вышеприведенные соображения указывают на критическую проблему системного формирования источников доходов бюджета подразделений местного самоуправления, в частности, включая поиск оптимального соотношения доходов, которые называются собственными и внешними доходами, включая в этом случае трансферты из государственного бюджета и субсидии из государственных средств. Высокий уровень собственного дохода, учитывая одновременно их стабильность, можно считать одним из жизненно важных факторов финансовой независимости местного самоуправления. Это, в то же время, не уменьшает значения внешнего дохода, поскольку, несмотря на его, безусловно, ограничивающий характер финансовой независимости, данный доход является важным элементом региональной политики, выполняя функцию поддержки в выбранных сферах и в то же время контролируя отдельные сферы финансовой экономики местного самоуправления через государственные учреждения государственного управления. Анализируя проблему независимости, мы должны, таким образом, определить сферу свободы, которой фактически владеют подразделения местного самоуправления, не только в отношении объединения бюджетных средств, но и в отношении их расходования. Чем больше масштаб такой независимости органов местного самоуправления, тем более автономными становятся субъекты, которые принимают участие в процессе развития.

Если предположить упрощенный подход к вопросу финансовой независимости, исходя из характеристик вышеупомянутой категории доходов, можно констатировать, что независимость в отношении дохода может быть обеспечена только тогда, когда доминирующую роль в финансировании органов местного самоуправления будет играть собственно доход. Что касается самостоятельности трат, то вона увеличится вместе с увеличением доли собственного дохода и общих субвенций в структуре доходов подразделений местного самоуправления. В соответствии с этим подходом было бы намного проще обеспечить 
самостоятельность в отношении затрат, поскольку как собственный доход, так и общая субвенция распределяются на основе решений, принятых законодательными и исполнительными органами местных органов власти.

Анализ фактической степени финансовой независимости местного самоуправления представляется достаточно сложной задачей, учитывая неоднозначную оценку критериев этих проблем. Тем не менее, можно использовать анализ определенных индексов, включая индекс оценки доли собственного дохода подразделений местного самоуправления в доходе сектора государственных финансов общего объема либо индекс доли собственного дохода единиц местного самоуправления в его доходе в целом. Рост размеров этих индексов обозначает улучшение финансовой независимости местного самоуправления.

Ухудшение экономической ситуации и снижение доходов в реальной сфере приводят к ограничениям текущей деятельности, уменьшению издержек (часто за счет снижения уровня занятости) и ограничению уровня инвестиций, а также росту доли принятия решений о частичном прекращении или полном прекращении предпринимательской деятельности. С точки зрения государственного сектора вышеописанные явления приводят к значительному риску уменьшения объемов налогов в государственный бюджет, из которого части перечисляются в бюджеты органов местного самоуправления. Характерная тенденция современных систем государственного финансирования в бюджетный доход «зависеть от объема государственных сборов» вызывает усиление чувствительности государственного сектора как к изменениям в реальной экономике, так и к перекрестным отношениям. Пример экономической ситуации в некоторых развитых странах в сравнении с замедлением экономики во многих странах ЕC в период после 2008 года указывает на ведущую роль субъектов государственного сектора в формировании явлений развития в условиях финансового кризиса и привлечения существующих источников финансирования государственных расходов. Отсутствие активности государственного сектора создаст дополнительное ухудшение состояния институциональной инфраструктуры, ослабление регуляторных функций 
государственного управления и снижение качества государственных услуг, что, как следствие, ухудшит условия управления для частного сектора.

В процессе анализа было сделано допущение относительно эквивалентности условий развития и инвестиций - инвестиционные издержки можно считать эквивалентом развития. Это вытекает из суждения, что с помощью инвестиций поддерживается экономический потенциал, позволяя увеличить его масштабы как количественные, так и качественные, а также обращаясь к государственным услугам, в том числе социальным. Что касается подразделений местного самоуправления, принцип разработки зафиксирован в плановых документах стратегического характера, включая проекты, которые касаются количественных и качественных изменений в будущих периодах.

Финансирование задач местного самоуправления до сих пор строго связано с необходимостью догонять развитие в сфере инфраструктуры как экономической, так и социальной. Несмотря на благоприятную ситуацию в отношении способности генерировать средства, выделенные на инвестиционные проекты, следует уделять больше внимания вопросам участия внешнего капитала в финансировании инвестиционных расходов, а также вопросам роста государственного долга, которые являются факторами, указывающими на наличие структурного несоответствия базы бюджетных доходов фактически определенным в них условиям потребностей социальных служб местных общин.

Важным вызовом в процессе принятия решений касательно начатых инвестиционных проектов органами местного самоуправления является рациональность расходования государственных средств. Поэтому на этапе подготовки планов развития либо инвестиционных программ следует усовершенствовать методы анализа относительно экономической эффективности конкретных инвестиционных проектов, а также влияния конкретного проекта на функционирование местной экономики. Услуги общего интереса и социальные услуги обычно характеризуются низкой ценовой гибкостью и доходом спроса, а это означает, что как изменения, происходящие со стороны цен, так и доход мало влияют на изменения спроса, а поэтому, и на уровень 
спроса. Явление низкой гибкости спроса в данной сфере услуг имеет специфическое влияние на весь процесс предоставления услуг. Кроме того, некоторые государственные услуги, особенно социальные, предоставляются бесплатно, а это значит, что их эффективность невозможно оценить только с помощью инструментов финансового анализа. Аналогично инвестиции, вложенные для увеличения основных фондов обслуживания предоставленных услуг, должны, в значительной степени, оцениваться с применением инструментов, позволяющих измерять не только финансовые эффекты, но и влияние на состояние природной среды и социальные эффекты, формирующие будущую привлекательность районов территориальной единицы как места проживания и развития местного предпринимательства.

Принимая во внимание ожидаемые ограничения наличия внешнего инвестиционного капитала, не подлежащего возврату, в бюджетной экономике определенной единицы местного самоуправления есть важный элемент, заключающийся в поддержании баланса бюджета и безопасного уровня задолженности. Учитывая недостаточный уровень социально-технической инфраструктуры, который все еще присутствует в многочисленных подразделениях местного самоуправления, и явление, связанное с этой недостаточностью, а именно ожидание касательно более быстрого удовлетворения коллективных социальных потребностей, много подразделений берут на себе реализацию капиталопоглощающих инвестиций в материальные активы. Слишком высокий уровень задолженности и связанные с этим долгосрочные задолженности могут значительно заблокировать или уменьшить возможность определенного подразделения создавать новые инвестиционные проекты. Такие проблемы возникают достаточно часто. В переходный период можно возобновить структуры государства и общества и направить социальноэкономические процессы на путь развития. Многочисленные трудности в функционировании государства и предоставлении услуг в государственном секторе все еще существуют в бедных странах. В более широком контексте во многих бедных странах мира дилеммы развития все еще ждут эффективных решений. 
Как было обозначено ранее, в условиях рыночной экономики социально-экономическое развитие является результатом предпринимательских задач, которые реализуются в организациях, работающих на открытом рынке. Таким образом, можно сформулировать вывод о том, что потребность во взаимодействии субъектов государственного сектора и частного сектора вытекает из того, что подразделения местного самоуправления отвечают только за небольшой спектр задач, включая преимущественно государственные.

На данном этапе стоит обозначить важность динамично возрастающих групп участников процесса развития на местном уровне - сотрудничества органов местного самоуправления с негосударственными организациями в отношении предоставления услуг и социальных инвестиций. Организации, которые рассматриваются как часть сектора неприбыльных организаций и составляют одновременно объекты социальной экономики, могут рассматриваться как важная и все еще развивающая группа участников социально-экономических процессов в странах ЕС, и которые постепенно решают значительную часть социальных задач, до недавнего времени традиционно принадлежащих государству.

Результаты анализа дают основания утверждать, что роль субъектов хозяйствования частного сектора и субъектов государственного сектора в процессах социально-экономического развития является, безусловно, значительной. Подразделения органов местного самоуправления до сих пор отвечают за формирование явлений развития. Однако эта роль остается ограниченной, тогда как центр тяжести экономических эффектов был перенесен в реальную сферу и частный сектор. Финансовая независимость органов местного самоуправления была ослаблена изза того, что органы местного самоуправления стали значительно зависимыми как от внешних, так и от возвращенных источников финансирования. В частности, возмещаемые источники финансирования, предназначенные для достижения инвестиционных целей, имеют долгосрочное измерение. Решения, принятые в таких случаях, могут иметь свои долгосрочные последствия, превышающие текущий срок полномочий органов местного самоуправления, принимающих участие в процессе принятия 
решений. Несмотря на существующие гарантии непрерывности принятия решений в государственном секторе управления, необходимо подчеркнуть важность непосредственной ответственности за любые потенциальные последствия осуществленных действий, которые могут негативно повлиять на бюджетную ситуацию в будущих периодах. Как следует из проведенного анализа, ответственность за принятие решений относительно развития и их будущие экономические и социальные результаты являются одними из наиболее значительных и одновременно самых сложных элементов участия субъектов государственного сектора в экономике на местном уровне и в процессе формирования и стимулирования его развития. Среди проблем, которые все еще остаются в силе, мы должны перечислить надлежащую оценку потребностей социальных служб, усовершенствование процессов подготовки инвестиционных проектов, включая учет всех соответствующих инструментов планирования и оценки материального и финансового объема проектов, а также ответственность местного самоуправления, которое проявляется в реализации инвестиционных проектов, всесторонне описывая все сферы функционирования данного подраздела. Учитывая весь прошлый опыт, связанный с функционированием органов местного самоуправления в странах ЕС, следует указать, что эти субъекты ответственны за значительную сферу предоставления государственных услуг, включая социальные услуги, которые зачастую предполагают привлечение капиталовложений. В связи с этим существуют серьезные ограничения, которые заключаются в несоответствии объемов мер и объемов задач. Результатом данного несоответствия является поиск подразделений местного самоуправления для источника внебюджетного характера, включая преимущественно источники, которые возвращаются. Однако это может быть ограничением в будущих возможностях финансового развития. Организация социальных служб все еще является сложным процессом. Данные услуги характеризуются высоким спросом на инвестиционный капитал и высокими операционными издержками. Важной особенностью социальных услуг является безоплатность, означающая, что все издержки, связанные с их предоставлением, 
финансируются государственными структурами, а граждане получают услуги бесплатно.

Быстрое развитие новых платформ и технологий ускорило развитие и темпы роста сектора финансовых услуг, что обратило больше внимания регуляторов и политиков в разных юрисдикциях.

По всему миру развитие финансовых технологий делает революцию в сфере способа взаимодействия людей с финансовыми услугами. Эти нововведения позволяют быстрее осуществлять платежи, более безопасные транзакции, уменьшить издержки на перевод средств и позволяют финансовый доступ в сферах, где традиционные финансовые инструменты использовать невозможно.

Оцифровка сегодня становится частью всего, и предприятия не являются исключением. Множество предприятий в мире (особенно в Северной Америке) имеют цифровое образование, и поэтому они имеют ежегодно высокую рентабельность, и ее преимущества отражаются в ВВП страны и уровне занятости.

Украина только начинает свой путь, потому что у нее очень низкий уровень инвестиций в НИИКР и нет полной цифровой трансформации из-за инертности сотрудников и финансовой неприязни руководства, поскольку цифровую трансформацию считают очень дорогим шагом, который не продемонстрирует мгновенной пользы в ближайшем будущем.

Стоит отметить, что европейские фонды играют значительную роль в финансировании инвестиций в цифровую трансформацию и инновации. 


\section{РАЗДЕЛ 2. КОМПЛЕКС БАЗОВЫХ ПОНЯТИЙ ФЕНОМЕНА «ЦИФРОВОЙ АКТИВ»}

Современный этап экономического развития общества характеризуется формированием новой сферы экономики цифровой, обусловленной увеличением роли цифровых технологий и электронно-информационных технических средств связи в развитии всех основных отраслей науки. Цифровые технологии, появившиеся на протяжении последнего десятилетия, помогают найти источники повышения эффективности и возможности стремительного конкурентного развития рыночных бизнес-структур. В то же время они требуют перестройки имеющихся бизнеспроцессов на основе новых ценностей, приоритетов и ориентиров, основанных на клиентоориентированности, инновационности, уникальности, праве использования и передачи, синергии.

Развитие цифровой экономики в целом и цифровых технологий в частности обусловило появление нового понятия - «цифровой актив» - и стремительное развитие связанных с ним процессов.

На сегодняшний день понятие «цифровой актив» не имеет единого комплексного определения, которое полностью раскрывало бы суть термина, что значительно усложняет понимание многих процессов, связанных с использованием цифровых активов, и достаточно часто влияет на искажение и ошибочное трактование информации, заложенной в базис существования цифровых активов. Подобная терминологическая путаница создает устойчивые условия для дальнейшего укоренения противоречивости и неоднозначности не только самого понятия «цифровой актив», но и перспектив его использования. Поэтому актуальным является уточнение понятия цифрового актива.

Анализ современных научных публикаций и исследований по вопросу цифрового актива свидетельствует, что сегодня не существует четкого определения и понимания этого понятия.

Так, одна группа ученых [9-18] применяет понятие «цифровой актив»; другая группа [19-21] - понятие «криптовалюта»; третья группа [22] - понятие «токен»; четвертая группа [23] - понятие «виртуальный актив»; пятая группа ученых [24-26] применяет 
несколько понятий одновременно в качестве синонимов, то есть наблюдается тесное переплетение понятий.

Во время разработки терминологического аппарата нами учитывались рекомендации ДСТУ 3966-2000 [27].

Для обоснования сущности понятия «цифровой актив» в экономико-правовом аспекте был использован комплекс теоретических методов исследования: дедукции и индукции, анализа и синтеза, сравнения, обобщения, систематизации и интерпретации результатов.

Уточнение понятия цифрового актива должно базироваться на четком терминологическом определении собственно дефиниций «цифра» (производное «цифровой») и «актив».

Изначально словом «цифровой» обозначался термин, описывающий информацию, выраженную посредством чисел. Данные, такие как изображения, звуки, слова, представляются в виде набора цифр (1 та 0) в двоичной системе, что получает свое непосредственное применение в компьютерной сфере [28]. В Толковом словаре понятие «цифровой» рассматривается как переводящий с использованием электронных систем информацию в двоичный код, предназначенный для последовательной обработки, сохранения и передачи соответствующей информации. Эти определения подтверждают, что термин «цифровой» тесно связан с процессами распространения, интеграции информации и информационных технологий в различные сферы деятельности и является неотъемлемой частью понятий и процессов, характеризующих изменения, происходящие не только в финансовоэкономическом секторе, но и в обществе в целом.

Также следует рассмотреть содержательное наполнение понятия «актив». В Толковом словаре финансов понятие «актив» трактуется как предмет объективной действительности, будь он материальный или же нематериальный, который имеет некую ценность для его держателя [30]. В Энциклопедическом словаре [31] в качестве актива определяются составные части имущества, без учета имеющихся долгов, то есть товары, наличные деньги, ценные бумаги, векселя, машины, инструменты, земли и постройки и т. д. В свою очередь, в Современном экономическом словаре одно из токований понятия «активы» раскрывается как совокупность денег, 
имущества, принадлежащих субъекту хозяйствования (фирме, предприятию, компании), в которые предварительно были вложены средства их владельцев [32].

В ходе рассмотрения понятия «цифровой» выявлено, что оно включает в себя и числовые комбинации, и кодирование разных видов и способов, и технологию перевода чего-либо в электронный формат (оцифровка). В большинстве источников понятие «актив» связано с материальными или нематериальными ресурсами и имущественными правами. Это своего рода ценность, владельцем которой может быть как один человек, так и предприятие или общество в целом. Совместив эти два понятия, можно определить цифровой актив как ценность, выраженную в цифровом виде. Исходя из этого, цифровой актив представляет собой набор цифровых (двоичных) данных, которые являются автономными, уникально идентифицируемыми и имеют определенную ценность.

Использование термина «цифровой актив» в современном понимании в первую очередь вызвано появлением технологии Блокчейн и криптовалют. В 2009 году была создана первая криптовалюта Bitcoin, которая стала новым феноменом в сфере экономики. Одновременно с Bitcoin была разработана и технология Блокчейн - распределенный реестр, представляющий собой выстроенную по определенным правилам последовательную цепочку из блоков транзакций, где каждый последующий блок содержит информацию о предыдущем. Данная логика работы Блокчейна позволила обеспечить безопасность и прозрачность транзакций и происходящих в нем процессов, благодаря чему эта технология нашла свое применение во многих сферах. Такие тенденции обусловили стремительное развитие цифровой экономики и вызвали высокий интерес общества к феномену цифровых активов. Однако ввиду неоднозначного трактования и отсутствия базовых критериев определения, термином «цифровой актив» часто называют то, что на самом деле им не является.

Итак, при уточнении понятия цифрового актива будем придерживаться определенных сущностно-смысловых особенностей, представленных четырьмя составляющими: 1) экономической; 2) правовой; 3) информационной; 4) ценностной. 
Рассмотрим их подробнее, базируясь на таких методах исследования: дедукции и индукции, анализа и синтеза, сравнения, обобщения, систематизации и интерпретации результатов.

1. Экономическая составляющая в контексте определения понятия «цифровой актив». Эта составляющая представлена в финансовой сфере наличием уникального идентификатора.

Для того чтобы обосновать целесообразность использования компоненты «В виде уникального идентификатора» в определении цифрового актива, рассмотрим дефиниции по отдельности. Согласно Толковым словарям [29; 33] слово «уникальный» обозначает единственный, редкий, неповторимый, исключительный, редкий или же такой, что существует в единственном экземпляре. Слово «уникальный» происходит от латинского unicum и обозначает «единственный». Из всего разнообразия толкований «уникальный» необходимо отталкиваться от значения «единственный в своем роде» для правильного понимания данного понятия в определении цифрового актива.

В век информационных технологий и развития компьютерной техники термин «идентификатор» прочно ассоциируется с информационной средой. Например, в качестве идентификатора в сети может использоваться Email, номер телефона или код.

Значение слова «идентификатор» в Большом толковом словаре современного украинского языка [34] звучит следующим образом: идентификатор (от англ. identifier) - имя объекта программы (переменной, массива, структуры, функции и т. д.), что позволяет обратиться к объекту; признак, который в целом определяет сущность в заранее определенном пространстве. Идентификатор всегда: а) единственный - рассматривается как неделимая (атомарная) лексема; б) тождественный - указывает только на одну сущность; в) действителен только в одном адресном пространстве.

Сущностная характеристика идентификатора хорошо отражается в задачах языков программирования в определении границ действия локальных изменений [34]. В Кратком словаре по кибернетике идентификатор представлен в качестве условного наименования (метки, имени) совокупности информации либо же группы данных, что позволяет найти и, соответственно, извлечь такую информацию из памяти [35]. 
Для внесения ясности в порядок предоставления документов в государственный реестр и регулирования оборота электронных документов юридических и физических лиц используется термин «уникальный идентификатор» - логическая последовательность символов, с помощью которых заявитель передает на официальном веб-сайте специального уполномоченного органа по вопросам государственной регистрации информацию о состоянии рассмотрения направленных им электронных документов для регистрации юридического лица или физического лица предпринимателя, а также получает электронные документы, которые направлены ему государственным регистратором [36]. Понятие «уникальный идентификатор» также используется в сфере проведения электронных аукционов и обозначает набор цифр и букв, который аукционная платформа автоматически присваивает какойлибо распределенной пропускной способности, что была распределена между пользователями согласно результатам электронного аукциона [37].

Уникальный идентификатор применяется в информационных системах и предназначен для идентификации определенного объекта в сети, а также позволяет исключить любую вероятность дублирования этого объекта и подтверждает его подлинность.

Основываясь на рассмотренных интерпретациях понятий «уникальный», «идентификатор» и словосочетания «уникальный идентификатор», можем сделать вывод, что компонента «В виде уникального идентификатора» указывает на форму представления цифрового актива и свидетельствует о наличии уникального имени. Буквенно-числовой код, присваиваемый системой, в которой обращается цифровой актив, позволяет отличить конкретный цифровой актив в распределенном реестре данных и получить необходимую информацию о нем.

Свойство уникальности цифрового актива стало возможным с появлением технологии распределенного реестра, структура которого как раз и является гарантом сохранения информации и возможности верификации актива. Любые вносимые изменения в распределенном реестре (Блокчейне) автоматически приводят к генерированию нового уникального идентификатора, что исключает возможность дублирования и неправомерного использования актива. 
Информация о цифровом активе содержит такие признаки: место его нахождения, регистрации, законодательные ограничения и другие отличительные признаки и свойства. Блокчейн обеспечивает условия идентификации цифрового актива за счет присвоения ему уникального хеш-кода, что позволяет закрепить такой актив за определенным субъектом.

2. Правовая составляющая в контексте определения понятия «цифровой актив». Эта составляющая представлена в юридической сфере производной от права.

Для корректной интерпретации компоненты «Производный от права» необходимо определить дефиниции: «производный» и «право». В первую очередь следует обратиться к материалам словарей. Так, согласно Толковому словарю [29] под производным нужно понимать произведенный или же образованный от другого объекта. В Толковом словаре [33] в качестве производного предлагают понимать то, что проистекает из чего-нибудь другого, либо же образованно от чего-то другого.

В дальнейшем считаем целесообразным рассмотреть термин «право». Стоит отметить, что полипарадигмальный подход к пониманию права обусловлен истоками возникновения данного феномена, многовековой философской полемикой вокруг него и, как следствие, неоднозначностью толкования. Более того, данное слово является многозначным и используется в повседневной речи для обозначения разных феноменов. Трехаспектное понимание термина «право» было предложено в Толковом словаре русского языка [38], где право рассматривается как: а) формализованная совокупность правил поведения; б) наука, которая изучает соответствующие формализованные правила поведения; в) мера возможного поведения, свобода действий, предоставляемая государством.

Стоит отметить, что именно последний способ интерпретации права в толковании Ушакова Д. Н. [38] является наиболее близким к истинному пониманию в контексте определения понятия «цифровой актив». Именно эта языковая конструкция будет использована в авторском определении понятия цифрового актива - «право на». В данном случае «право» можно заменить на «гарантированная возможность чего-либо», при этом исходный смысл будет сохранен. 
Подразделение права на его объективное и субъективное понимание было применено в том числе и в Большом юридическом словаре [39]:

а) объективный смысл права - совокупность официальных норм права, что устанавливаются и обеспечиваются государством (позитивное право); правила, которые проистекают из самой природы права, что стоит над формальным законом (естественное право);

б) субъективный смысл права - мера возможного поведения субъекта права (субъективное право).

Таким образом, именно субъективный смысл трактования права в данном источнике апеллирует к рассматриваемому определению понятия «цифровой актив». Матузов Н. И. и Малько А. В. [40], с точки зрения правовой доктрины, определяют право как нормированную, упорядоченную форму проявления свободы, которая направлена в легитимное русло.

Проанализировав значения разных понятий слова «производный», можно прийти к общему заключению: все эти обозначения объединяются наличием определенного базового явления, предмета (производящего), которое и обуславливает происхождение производного. Другими словами, «производный» возникает в результате трансформации производящего (базового явления) и при этом способен сохранять базовые свойства либо опираться на них. В свою очередь, свойства производных предопределены свойствами производящих.

Опираясь на вышеизложенные определения права, можно сделать вывод, что в определении понятия «цифровой актив» будет использован именно субъективный подход трактования права как вид и мера возможного поведения лица, которые регламентируются правовыми нормами.

По результатам анализа дефиниций компоненты «Производный от права» можно утверждать, что они наиболее полно отображают суть заложенного в определении понятия «цифровой актив» принципа. Цифровой актив не является правом на ценность в его толковании, однако он обладает свойствами производного от права на ценность. 
3. Информационная составляющая в контексте определения понятия «цифровой актив». Эта составляющая представлена в ITсфере информационным ресурсом, обращающимся в распределенном реестре.

Компонента «Информационный ресурс» на сегодняшний день не имеет универсального всеобъемлющего определения. Толкования данного термина варьируются в зависимости от предметных областей и подходов, в разрезе которых он рассматривается.

В законодательных актах понятие «информационный ресурс» определяется как:

a) совокупность документов в информационных системах (библиотеках, архивах, банках данных и т. д.) [41];

б) организованная совокупность документированной информации, включающая базы данных, другие совокупности взаимосвязанной информации в информационных системах [42].

Понятие информационных ресурсов, сформированное в Энциклопедии современной Украины [43], определяет эти ресурсы как информацию, представленную в конкретной форме и соответственно хранящуюся, накапливающуюся, обрабатывающуюся и используемую заинтересованными лицами. Информационные ресурсы характеризируются своеобразной эмерджентностью, так как информационный ресурс может способствовать формированию новых знаний. Интерпретированы информационные ресурсы могут быть как человеком, так и компьютерной программой. Долинко В. И. [44] отмечает, что информационный ресурс - это данные в любой форме, которые характеризуются возможностью их многократного использования. В Финансовом словаре [45] информационные ресурсы определяются как совокупность данных, которые систематизированы для последующего эффективного получения необходимой информации.

Поляков В. П. и Косарев В. П. [46] акцентируют внимание на том, что в XX веке значение информации как никогда начинает возрастать. Соответственно, это привело к появлению на одном из конгрессов ЮНЕСКО такой устойчивой терминологической конструкции, как «информационные ресурсы». Информационные ресурсы, по мнению авторов, являют собой продукт интеллектуальной деятельности. Особенной чертой 
информационных ресурсов, как отмечают Поляков В.П. и Косарев В. П. [46], является тот аспект, что они не исчезают по истечении некоторого периода времени. В свою очередь Шуремов Е. Л. [47] детерминирует информационные ресурсы как знания, которые были зафиксированы на материальном носителе и могут в дальнейшем быть применены заинтересованными лицами. При этом стоит обратить внимание на позицию Прокопенко А. Н. [48], который говорит, что информационным ресурсом является не любая информация, а только та, которая была надлежащим образом упорядочена и структурирована. Что же касается Бачило И. Л. [49], то она отмечает, что информационным ресурсом является только та информация, которая имеет практическую значимость, что придает ему социальной значимости.

Из всех вышеуказанных определений и уточнений данного понятия можно сделать вывод, что информационный ресурс - это структурированная и организованная определенным образом информация, зафиксированная на материальном носителе, которую можно хранить, передавать, использовать, пополнять. Информационный ресурс обладает свойствами практической значимости и полезности, а также возможностью многократного использования («неисчерпаемостью»). В отличие от других видов ресурсов (природные, экономические, временные) количество и качество информационных ресурсов возрастает по мере их использования. Такой кумулятивный эффект наряду с развитием современных технологий способствует стремительному приумножению информационного потенциала общества в целом.

Таким образом, цифровой актив является информационным ресурсом в том смысле, что представленная в цифровом виде информация о ценности обладает такими основными свойствами информационного ресурса, как: а) информация структурирована по определенным параметрам и категориям; б) информация фиксируется на цифровом носителе; в) информацию можно хранить, передавать, обменивать, использовать и т. п.

Помимо этого, цифровой актив в нашем понимании имеет дополнительное свойство - информация о ценности формируется владельцем этой ценности. Следует отдельно отметить, что информационный ресурс в контексте определения понятия 
«цифровой актив» лишается такой характеристики, как возможность быть скопированным неограниченное количество раз. Это обусловлено тем, что в распределенном реестре каждый такой ресурс выражен в виде уникального идентификатора, благодаря чему обеспечиваются устойчивые условия гарантированной принадлежности цифрового актива определенному субъекту. Отсюда вытекает следующее важное заключение: ценность цифрового актива состоит в его уникальности и достоверности, которые обеспечиваются благодаря обращению цифрового актива в распределенном реестре. Основываясь на этих характеристиках, можно обозначить также высокую практическую значимость цифрового актива в экономико-правовом аспекте.

Компонента «Обращающийся в распределенном реестре» в контексте определения понятия «цифровой актив».

Рассмотрим понятие «обращающийся», опираясь на различные источники информации. Так, в Финансово-инвестиционном толковом словаре [50] понятие «обращающийся» употребляется в контексте кредитно-денежных или же финансовых ценностей, которые подлежат дальнейшей передаче или же продаже другому субъекту. Учитывая, что данное понятие чаще всего используется вместе с существительными, наиболее полно раскрыть его значение можно в контексте. Так, в Финансовом словаре [51] дается определение понятия «обращающиеся инструменты», под которыми понимаются финансовые инструменты и ценные бумаги, что могут быть объектом свободного гражданского (хозяйственного) оборота (например, векселя, облигации, чеки, варранты). Дополнительно следует учесть и синонимический ряд к рассматриваемому термину для более широкого понимания его значения: обращающийся использующийся, циркулирующий, курсирующий, переходящий.

Также необходимо рассмотреть смысловое наполнение такой категории, как «распределенный реестр». Понятие «распределенный реестр» имеет достаточно много определений. Так, по данным Департаментов исследований, статистики и денежной политики Федеральной Резервной Системы США, распределенный реестр - это тип базы данных, которая разделена между узлами сети; определенная комбинация компонентов, включающая, помимо прочего, peer-to-peer networking, распределенное хранение 
информации и криптографию, которая может потенциально изменить то, как цифровой актив будет храниться, регистрироваться и торговаться [24].

По словам главного научного советника Правительства Великобритании Уолпорта М., распределенный реестр - это база данных активов, которая может распределяться по сети различных сайтов, в различных организациях и географических зонах. Также нужно отметить, что все участники сети могут иметь свою идентичную, личную копию соответствующего реестра. Изменения, которые вносятся в реестр, тут же отображаются во всех копиях. Сами же активы, которые находятся в реестре, могут быть юридическими, финансовыми, электронными или же физическими. Достоверность и безопасность хранимых активов обеспечивается криптографически [52]. Данная новая технология распределенного хранения информации именуется Блокчейн. Эта технология дает возможность в том числе вести учет операций как с материальными, так и нематериальными активами. Технология Блокчейн позволяет оцифровать информацию; безопасно ее передавать. Преимущества этой технологии заключаются в следующем: неизменность; защищенность; прозрачность [53, с. 3-4].

Савельев А. [54] определяет «децентрализованный реестр данных» как информационную систему, которая включает базу данных распределенного типа и которая содержит информацию относительно конкретных фактов и (или) данные о праве на имущество, что подтверждается посредством определенных алгоритмов.

Одно из ключевых свойств цифрового актива - возможность обращаться в цифровой среде, а не копироваться при передаче с одного электронного адреса (хранилища, кошелька, ячейки) в другой. Обращающийся объект (цифровой актив) в обязательном порядке должен иметь не только свою среду обращения, но и четко обозначенные правила и условия своего нахождения в такой среде. Для возможности установления и контроля выполнения таких правил и условий необходима надежная цифровая экосистема, масштабируемая и децентрализованная, которая позволит всем участникам быть уверенными в сохранности уникальности информационных ресурсов. Именно поэтому компонента 
«Распределенный реестр» занимает значимое место в определении понятия цифрового актива.

Распределенная система хранения данных таких реестров является одной из самых технологически продвинутых. Она обеспечивает максимально возможный уровень доверия к информации благодаря обязательной процедуре ее проверки на достоверность всеми узлами распределенной среды посредством определенного способа обеспечения консенсуса. Тем самым решается также и проблема «двойного расходования». Информацию, содержащуюся в таком реестре, невозможно удалить или модифицировать, а надежность и механизм данного метода хранения позволяет создавать в реестре записи о праве на ценности (активы). Это является необходимой процедурой в процессе создания цифрового актива, который, в свою очередь, требует фиксации в реестре информации о проведении оценки (аудита) и других данных владельца оцифровываемой ценности, в частности, и его права собственности на ценность. Для понимания сути цифрового актива важно учитывать обязательные условия: возможность подтверждения принадлежности цифрового актива определенному субъекту, а также отсутствие каких-либо способов создания копии одного и того же цифрового актива, в том числе, путем дублирования его уникального идентификатора. Обеспечить такие условия может только технология распределенного реестра, которая позволяет гарантировать уникальность идентификаторов цифровых активов и зафиксировать конкретные идентификаторы за конкретными объектами.

Таким образом, можно сделать вывод, что возможность обращения в распределенном реестре для цифрового актива является одной из определяющих, следовательно, распределенный реестр как система хранения информации - единственно возможная среда существования и обращения цифровых активов, которые, по сути, являются токенизированными информационными ресурсами, производными от реальных активов в пространстве распределенного реестра.

4. Ценностная составляющая в контексте определения понятия «цифровой актив». Эта составляющая представлена в сфере материальных и нематериальных благ компонентой «Ценность». 
Понятие «ценность» имеет ряд определений и толкований, которые зависят от предметной области их применения. В Толковом словаре [55] понятие «ценность» рассматривается как стоимость конкретного объекта материальных или же нематериальных благ. Выделяется два подхода к детерминации стоимости. Так, с точки зрения классической политической экономии (Classical school) стоимость нужно рассматривать в качестве объективной реальности, которая измеряется посредством затраченного труда на производство тех или иных благ. В свою очередь, представители неоклассической школы (Neoclassical school) напрямую связывают стоимость с редкостью запрашиваемого блага. Превалирующим на сегодняшний день является именно неоклассический подход. Что же касается Энциклопедического словаря [56], то в нем ценность определяется как положительная либо же негативная значимость для человека объектов материального или же духовного мира. Вариативностью определений ценности отличается Толковый словарь русского языка [38]. Так, по мнению автора, в качестве ценности следует понимать значение, важность, цену конкретного явления или предмета.

Из приведенных толкований рассматриваемого понятия можно сделать вывод, что ценность - это значение стоимости, важности, полезности чего-либо, которая также может выражаться различными единицами измерения в зависимости от области практического использования такой ценности и экосистемы, в которой такая ценность существует.

В определении понятия «цифровой актив» будет использована формулировка «производный от права на ценность», так как, по сути, цифровой актив является своего рода гарантированным правом претендовать на определенное значение стоимости (на ценность), заложенное в данном цифровом активе. Другими словами, цифровой актив выступает токенизированным информационным ресурсом, производным от ценности. Таким образом, в определении понятия цифрового актива следует использовать именно компоненту «Ценность», так как она наиболее широко и всеобъемлюще выражает заложенный в него смысл.

На основании установленных сущностно-смысловых особенностей сделаем обоснование понятия «цифровой актив»в экономико-правовом аспекте. 
Цифровой актив - информационный ресурс, производный от права на ценность и обращающийся в распределенном реестре в виде уникального идентификатора.

Предложенное понятие «цифровой актив» представлено составляющими (экономической, правовой, информационной, ценностной), которые имеют взаимосвязь и взаимозависимость.

Рассмотрим более детально понятия, используемые в современных научных публикациях по вопросу цифрового актива.

На сегодняшний день ряд специалистов обозначают криптовалюты как разновидность цифровых активов. Так, ведущий криптоспециалист финтехкомпании Cinnober Wall [19] детерминирует Ethereum как цифровой актив. Аналогичный подход применяет Цегоев В. [21] к определению Bitcoin. Глава Ripple Garlinghouse [20] также склонен считать Bitcoin цифровым активом, аргументируя это тем, что Bitcoin предоставляет пользователю возможность решать конкретные реальные проблемы, что обусловливает наличие в нем определенной стоимости.

Существует также подход, в соответствии с которым отдельные категории токенов приравниваются к цифровым активам. Великая Е. [22] описывает utility token как цифровой актив, который дает держателю соответствующего токена право обменять его в будущем на продукцию или услуги, что непосредственно предоставляются эмитентом соответствующего токена.

Отдельная группа специалистов отождествляет цифровые активы с криптовалютой [24; 26$]$.

Специфический подход прослеживается в работе [25], где автор изучал отдельные аспекты налогообложения цифровых активов. Цифровыми активами выступают объекты, которые могут обращаться в системах Блокчейн. Ученый не сводит цифровые активы исключительно к криптовалютам, тем самым, как будто специально оставляя их перечень «открытым».

Social and economic foundation of the implementation of blockchain-based systems of digital assets in developing countries рассмотрены в работе [16].

Некоторые специалисты разделяют термины «криптовалюта» и «цифровой актив», указывая на принципиальную разницу данных понятий [9-18]. 
Buntinx J. P. [12] говорит о том, что цифровой актив существует в бинарном виде и им можно назвать любой тип цифровых данных: от кинофильма до папки на рабочем столе. Основным отличием цифровых активов от криптовалют он считает тип хранимых значений - у большинства криптовалют есть лимит предложения, тогда как цифровые активы могут (теоретически) создаваться бесконечно, если это необходимо.

Схожий подход к определению понятия цифрового актива был предложен исследователями групп компаний Центра инновационных технологий [9], которые обозначают в качестве цифрового актива любые события, факты, их характеристики и описания, которые были трансформированы в цифровую форму и, соответственно, обладающие некой стоимостью. Так, к цифровым активам относят такие элементы, как пароли, цифровые изображения, медицинскую информацию, инструктивные записки и любые другие элементы, доступ к которым осуществляется главным образом с помощью цифровых средств, таких как книги, музыка и фильмы. В то же время среди цифровых активов (с юридической точки зрения) принято также выделять объекты интеллектуальной собственности, а именно: авторские права, торговые марки, патенты и т. д. [17].

Harbinja E. [15, c. 102] и Walker M. D. [18, с. 53] под цифровым активом понимают любые объекты, которые имеют оцифрованную форму.

Более комплексными являются определения цифрового актива, которые получили свою формализацию в законодательных актах. В Fiduciary Access to Digital Assets and Digital Accounts Act [13] получило свое закрепление следующее определение цифрового актива: цифровой актив - это данные, текст, электронные письма, документы, аудио-, видеоизображения, звуки, контент социальных сетей, коды, записи о медицинском обслуживании, записи медицинского страхования, исходные коды компьютеров, компьютерные программы, программное обеспечение, программное обеспечение лицензий, баз данных и т. п., включая имена пользователей и пароли, созданные, генерируемые, отправленные, переданные, передаваемые, полученные или хранящиеся электронными средствами на цифровом устройстве. 
New York's Fiduciary Access to Digital Assets Act [14] гласит, что цифровой актив означает некоторую электронную запись, в отношении которой лицо имеет право или заинтересованность. Этот термин не включает базовый актив или обязательство, если этот актив или обязательство сами по себе не являются электронной записью. Указанные определения получили свою формализацию в действующих нормативных актах. При этом стоит обратить внимание в том числе и на определения, которые закреплены в проектах некоторых Законов. Так, в Проекте Закона Украины № 9083-1 [23] виртуальные активы определяются как токены и криптовалюта. Этот подход к определению цифрового актива можно обозначить как узкий, криптоориентированный подход.

Сапожков О. и Крючкова Е. [11] уточняют, что как права из бездокументарных ценных бумаг, так и доли в уставном капитале субъектов хозяйствования могут быть удостоверены электронными данными - «цифровыми правами». В свою очередь совокупность соответствующих прав, закрепленная за конкретным лицом, уже детерминируется «цифровым финансовым активом».

Арянова Т. [10] говорит о трех основных типах цифрового актива, к которым относятся: а) формальные - полностью централизованы и могут обозначаться как такие, которые переносят стоимость лишь формально; б) криптовалюты - полностью децентрализованы; в) гибридные - отдельные элементы инфраструктуры этих активов централизованы, притом что другие децентрализованы или же вовсе не существуют.

Это свидетельствует об образовавшемся разграничении в использовании данного понятия в сфере информационных технологий и в экономико-правовой сфере. Несмотря на поверхностную схожесть сути цифрового актива с представленными выше явлениями, единые критерии, полностью описывающие его природу и свойства, отсутствуют.

Проанализировав вышепредставленные подходы относительно понятия «цифровой актив», можно констатировать, что сегодня в обществе происходит подмена понятий, где чаще всего данным термином называют криптовалюту. Такие тенденции можно соотнести с достаточно неоднозначным статусом криптовалют и, 
следовательно, попытками минимизировать негативное отношение к изучаемому феномену.

Таким образом, проанализированы научные публикации и исследования по вопросу толкования понятия цифрового актива. Исследована сущность понятия «цифровой актив» на основе этимологического анализа. Предложенное понятие учитывает сущностно-смысловые особенности исследуемого феномена; характеризуется четырьмя составляющими: экономической, правовой, информационной, ценностной. Это позволило обосновать сущность понятия «цифровой актив» в экономико-правовом аспекте, выделить особенности использования этого понятия, а также уточнить взаимосвязь и взаимозависимость между его составляющими. 


\section{РАЗДЕЛ З. ВЛИЯНИЕ ЦИФРОВЫХ АКТИВОВ НА СОЦИАЛЬНО-ЭКОНОМИЧЕСКОЕ РАЗВИТИЕ И РОЛЬ ПРОГНОЗИРОВАНИЯ В УСЛОВИЯХ АНТИМОНОПОЛИЗАЦИИ ЭКОНОМИКИ}

На современном этапе социально-экономическое развитие стран мира испытывает все большее влияние от процессов цифровизации, которые меняют подходы к решению проблем на разных уровнях и в разных сферах жизни. Они в основном направлены на поиск новых возможностей для повышения благосостояния и решения настоятельных социальных проблем: от охраны здоровья, образования и окружающей среды.

В аспекте усиления и обострения проблем социальноэкономического развития национальной экономики возникает вопрос поиска результативной модели государственного управления экономики в Украине, одной из ключевых функций которой является прогнозирование. Данная проблематика является актуальной также, учитывая усиление проблем монополизации национальных рынков, сворачивание малого и среднего бизнеса. Антимонопольная политика государства, функционирование его институций и сама система антимонопольного регулирования экономики требуют детального исследования функции прогнозирования, ее роли и значения при формировании антимонопольной политики государства.

Основным заданием при прогнозировании социальноэкономического развития является определение количественных параметров и показателей относительно развития экономической системы в будущем. Существует два типа прогнозов:

- общие экономические прогнозы развития экономической системы в целом;

- прогнозы развития отдельных отраслей и сфер региональной экономики.

Общие экономические прогнозы - это разработка будущих сценариев развития, которая должна базироваться на возможных будущих ситуациях.

В рамках общего экономического прогноза следует определить наиболее общие показатели, которые могут быть ориентирами для дальнейшего развития. Эти данные могут быть основой для 
прогнозирования развития отдельных подразделений региональной системы.

Важной особенностью прогнозирования социальноэкономического развития является необходимость прогнозирования регионального развития не только как независимой системы, но и как части национальной экономики. Долгосрочные прогнозы особенно важны в управлении национальной экономикой и развитии региональных социально-экономических систем. Увеличение роли долгосрочных прогнозов является результатом условий формирования рыночной экономики; непоследовательность, а главное, отсутствие этих процессов не способствуют росту экономики.

Прогнозирование социально-экономического развития экономики не является новым вопросом для отечественной научной мысли. Такие ученые, как Грабовецкий Б. Е. [57], Стельмащук А. М. [58], Швайка Л. А. [59], Дикань Н. В. [60] и другие, занимались решением проблем сути, методов, инструментария прогнозирования. Тем не менее, несмотря на вышеуказанное, недостаточно исследованным является вопрос роли и значения прогнозирования в антимонопольном регулировании экономических процессов и прогнозирования влияния цифровых активов на социально-экономическое развитие.

Необходимым является определение сути, роли и значения прогнозирования социально-экономического развития для национальной экономики Украины, прежде всего в антимонопольной сфере деятельности государства.

Теоретической базой исследования выступают научные работы зарубежных и отечественных ученых. Для достижения поставленной цели были использованы следующие методы исследования:

- системный подход;

- метод анализа и синтеза;

- структурно-логический анализ;

- приемы логического обобщения.

Прогнозирование занимает главное место в системе функций государственного управления. Антимонопольная политика государства, ее результативность, эффект, возможный в связи с применением определенных ее инструментов, - вопросы, находящиеся в плоскости прогнозирования. 
Прогнозирование - многоаспектное явление, оно находится на пересечении наук, поэтому исследуется не только в экономике, но и в политике, социологии и других науках. Постоянно прогнозирование рассматривается рядом и во взаимосвязи с планированием как неразрывные и содержательно взаимозависимые государственнические функции. В данном исследовании необходимым является экономическое прогнозирование антимонопольного регулирования экономики в условиях цифровизации экономики.

В системе государственного антимонопольного регулирования функция прогнозирования также занимает видное место. Приоритетным направлением развития системы антимонопольного регулирования является смена общей концепции такого регулирования и внедрение европейской модели антимонопольной политики. Тем не менее можно уверенно утверждать о необходимости уточнения теоретических основ системы антимонопольного регулирования и построения ее структуры с учетом функции прогнозирования.

Целесообразным, на наш взгляд, является рассмотрение и исследование сути прогнозирования. Ученый Грабовецкий Б. Е. [57, c. 6] прогнозирование (от греч. - знание наперед) понимает как процесс формирования прогнозов на основе анализа тенденций и закономерностей развития объекта (процесса).

Стельмащук А. М. прогнозирование рассматривает как научное, обоснованное системой установление причинноследственных связей и закономерностей, выявление состояния достоверных путей развития явлений и процессов [58].

Швайка Л. А. рассматривает прогнозирование как определенную совокупность способов и приемов мышления, которые используются на основе внутренних и внешних изменений объекта прогнозирования для выявления возможных результатов изменений [59].

В целом при исследовании термина «прогнозирование» в экономической науке можно выделить два подхода в его понимании:

1) подход к пониманию прогнозирования как к определенному процессу (процессный) (Грабовецький Б. С., Стельмащук А. М., Кореева Е. Б.); 
2) системный подход к пониманию прогнозирования понимание прогнозирования как определенной системы составляющих (Швайка Л. А. и др.).

В дальнейшем под прогнозированием влияния цифровых активов на социально-экономическое развитие в условиях антимонопольного регулирования рынка будем понимать процесс разработки прогнозов на основе данных об объекте регулирования. Итак, прогнозирование антимонопольного регулирования экономики Украины в условиях цифровизации экономики должно базироваться на основе определенных фактических данных, их исследовании и взаимосвязи.

В научной литературе существует большое количество методов экономического прогнозирования. При выборе определенного метода прогнозирования необходимы ориентация в существующих методах, отбор наиболее актуальных и достоверных методов. С этой стороны необходимо выделить определенные критерии отбора методов прогнозирования, которые зависят от специфики объекта исследования.

Следует согласиться также и с учеными Дикань Н. В., Борисенко И. И. в работе [60], которые распределяют все методы прогнозирования на три группы:

- неформальные, количественные и качественные, относя к первой все виды неформальной информации, которая поступает к субъекту управления извне;

- расчетные методы, на основе которых разрабатываются прогнозы, основанные на внутренней информации и статистических данных;

- методы, применяемые, по мнению исследователей, в случаях, когда количественные методы слишком дорого стоят или же поступающая информация не надежна. В наиболее общем описании - это метод экспертных оценок специалистов определенной отрасли народного хозяйствования.

Система государственного антимонопольного регулирования экономики включает в себя все государственнические функции, в которые входят и прогнозирование антимонопольной деятельности государственных органов, прогнозирование поведения монополиста, потребителя и др. 
Принципы, на которых строится система антимонопольного регулирования экономики, приведены в таблице 1.

Таблица 1. Принципы построения системы антимонопольного регулирования экономики.

\begin{tabular}{|c|c|}
\hline Принцип & Характеристика \\
\hline $\begin{array}{l}\text { Принцип } \\
\text { системности }\end{array}$ & $\begin{array}{l}\text { Предусматривает, что построение и } \\
\text { внедрение системы антимонопольного } \\
\text { регулирования рассматривается не только } \\
\text { как самостоятельное звено, все элементы } \\
\text { которого взаимосвязаны и взаимозависимы, } \\
\text { но и как часть всех других направлений } \\
\text { государственного управления; акцентирует } \\
\text { внимание на системном анализе процесса } \\
\text { антимонопольного регулирования, четком } \\
\text { определении целей и критериев } \\
\text { антимонопольной работы; проведении } \\
\text { структуризации, раскрывающей весь } \\
\text { комплекс вопросов, которые подпадают под } \\
\text { действие антимонопольных органов. }\end{array}$ \\
\hline $\begin{array}{l}\text { Принцип } \\
\text { целеустремлен- } \\
\text { ности }\end{array}$ & 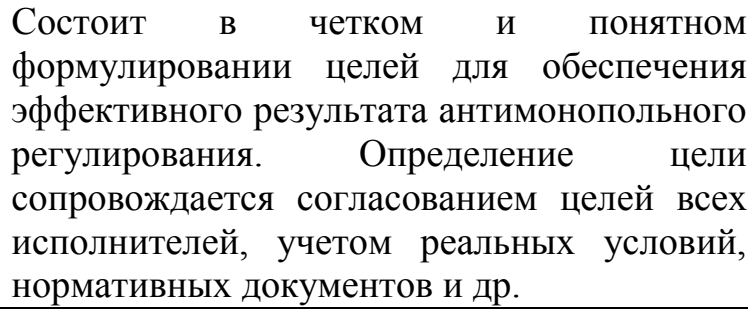 \\
\hline $\begin{array}{l}\text { Принцип } \\
\text { научности }\end{array}$ & 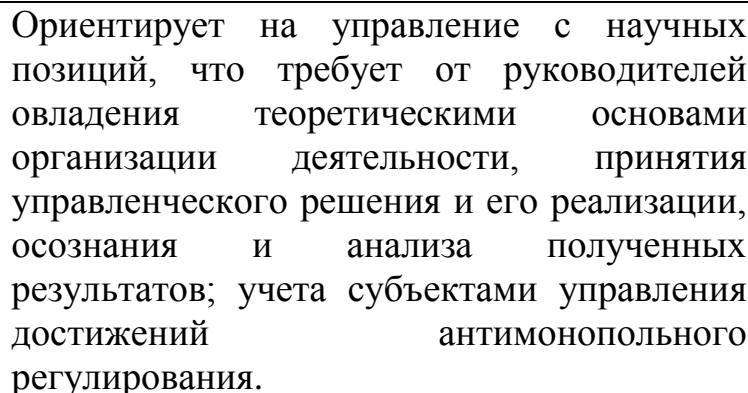 \\
\hline
\end{tabular}




\begin{tabular}{|c|c|}
\hline Принцип & Характеристика \\
\hline $\begin{array}{l}\text { Принцип } \\
\text { концептуальности }\end{array}$ & 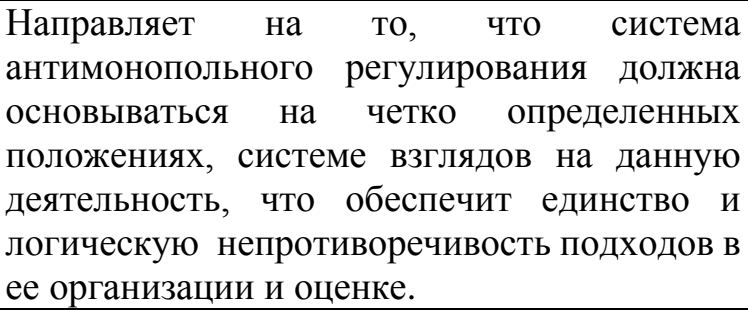 \\
\hline $\begin{array}{l}\text { Принцип } \\
\text { комплексности }\end{array}$ & $\begin{array}{lr}\text { Предусматривает } & \text { внутреннюю взаимосвязь } \\
\text { всех видов } & \text { антимонопольного } \\
\text { регулирования и дает возможность } \\
\text { преодолеть } & \text { односторонность } \\
\text { функционализм системы антимонопольного } \\
\text { регулирования. }\end{array}$ \\
\hline
\end{tabular}

Таким образом, обозначенные принципы должны стать основой деятельности в отношении антимонопольного регулирования, а также являются основополагающими при построении системы антимонопольного регулирования в условиях цифровизации экономики.

Прогнозирование, как и любой другой экономический процесс, строится на основе определенных методик и имеет определенную организационную структуру, этапность. В работах многих ученых предлагаются схемы этапности проведения процесса прогнозирования. При этом, на наш взгляд, процесс прогнозирования целесообразно рассматривать в контексте неразрывности его организационно-методического обеспечения.

Организационно-методическое обеспечение процесса прогнозирования предложено на рисунке 1.

Итак, при проведении прогнозирования антимонопольной деятельности государства необходимо учитывать его организационно-методическое обеспечение, владеть необходимой информацией о конкурентной ситуации на национальных рынках. 
Организационно-методические основы процесса прогнозирования

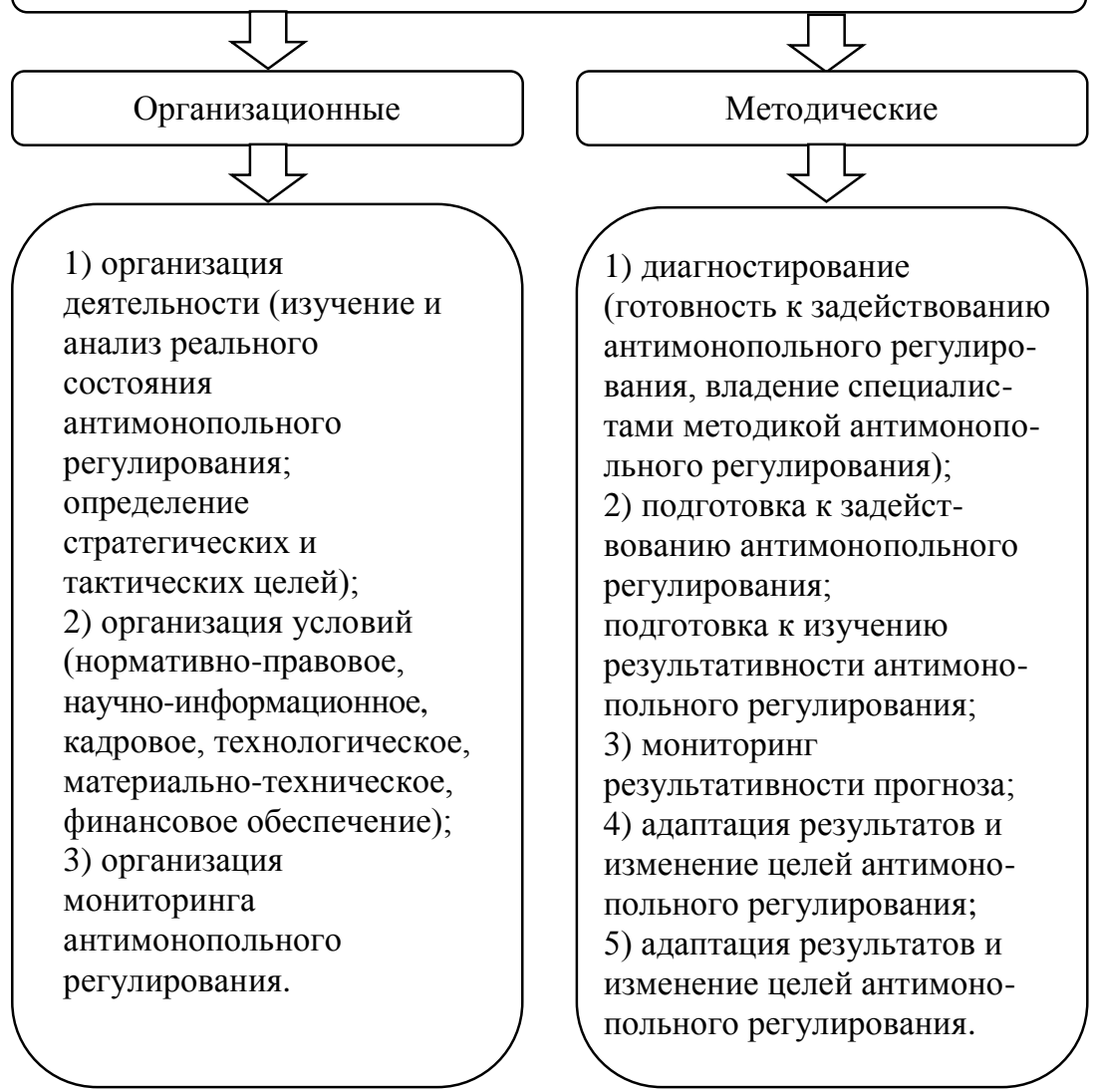

Рисунок 1. Составляющие организационно-методических основ процесса прогнозирования антимонопольного регулирования экономики в условиях цифровизации экономики.

Структурные предпосылки конкуренции в разных отраслях экономики формируются за счет учета определенных факторов. В частности, существенно на них влияют особенности функционирования каждой отдельной отрасли. Особенности функционирования каждой из отраслей обусловливают создание и функционирование соответствующей структуры рынка. 
Для более детального анализа разных рынков и особенностей их функционирования, опираясь на экономические показатели функционирования разных отраслей экономики, был проведен кластерный анализ этих отраслей.

Исходные данные для 2018 года представлены в таблице 2.

По результатам кластерного анализа отрасли экономики были разделены на 5 кластеров, которые представлены в таблице 3.

Для удобности каждой из отраслей экономики был присвоен свой порядковый номер в соответствии с их порядковым номером в таблице 3.

Данная классификация и разделение на кластеры разных отраслей экономики осуществлялись посредством анализа дендрограммы, полученной посредством использования пакета анализа «Статистика».

Дендрограмма представлена на рисунке 2.

Tree Diagram for 16 Cases Single Linkage

Euclidean distances

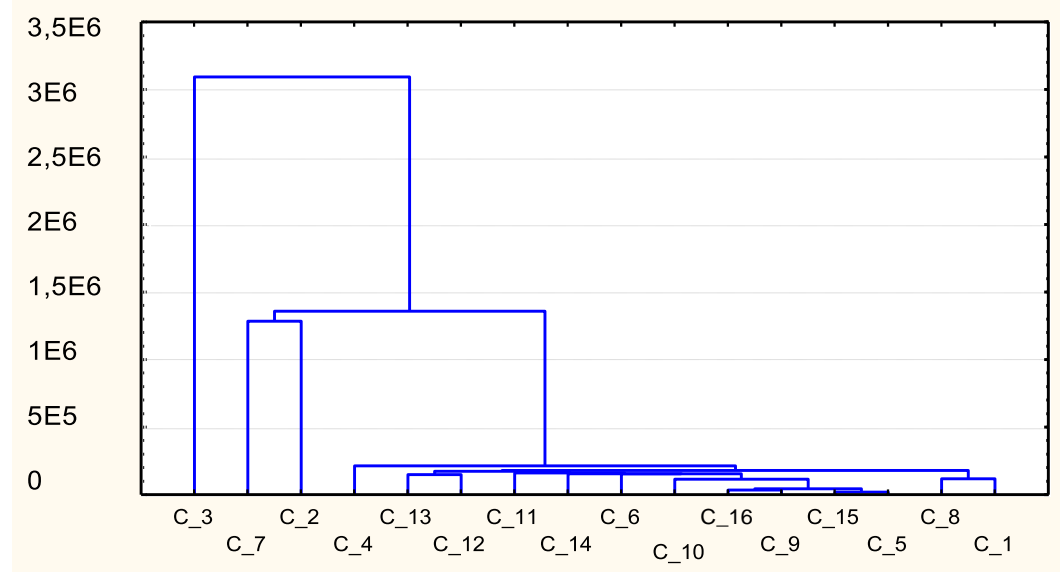

Рисунок 2. Диаграмма результатов кластерного анализа по 16 отраслям экономики. 


\begin{tabular}{|c|c|c|c|c|c|c|c|c|}
\hline 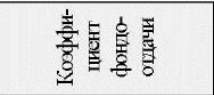 & $f_{-}$ & $\frac{尺}{\stackrel{8}{n}}$ & $\underset{-}{\stackrel{J}{\sim}}$ & बे & $\stackrel{\beta}{-}$ & $\begin{array}{c}\overrightarrow{6} \\
\mathrm{n}\end{array}$ & 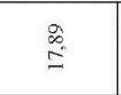 & $\bar{m}$ \\
\hline 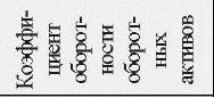 & $\stackrel{9}{\exists}$ & 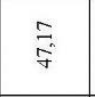 & $\stackrel{n}{=}$ & $\hat{\vec{N}}$ & $\overrightarrow{\vec{n}}$ & $\begin{array}{l}\text { मे } \\
\text { o. }\end{array}$ & त् & $\frac{\Delta}{i}$ \\
\hline ఏ & $\stackrel{\text { तु }}{*}$ & $\begin{array}{l}\frac{1}{6} \\
\frac{1}{10} \\
8\end{array}$ & $\begin{array}{l}\sqrt{n} \\
\infty \\
\infty \\
m\end{array}$ & $\begin{array}{l}7 \\
7 \\
0 \\
0 \\
0 \\
0\end{array}$ & $\begin{array}{l}\overrightarrow{\vec{G}} \\
\vec{f}\end{array}$ & $\mid$ & $\begin{array}{l}\mathscr{B} \\
\infty \\
\text { g } \\
y\end{array}$ & के \\
\hline 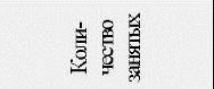 & 辛 & $\begin{array}{l}\mathscr{2} \\
\stackrel{8}{0}\end{array}$ & 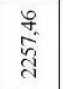 & $\begin{array}{l}\text { Bb } \\
\text { \&i }\end{array}$ & $\begin{array}{l}n \\
\text { in } \\
m\end{array}$ & 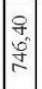 & $\begin{array}{l}R \\
\text { in } \\
2 \\
2\end{array}$ & 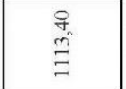 \\
\hline 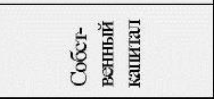 & $\begin{array}{l}8 \\
\text { \&ँ } \\
\text { gे } \\
\end{array}$ & है & $\begin{array}{l}\text { 㫘 } \\
\text { 䨪 }\end{array}$ & $\begin{array}{l}\frac{8}{8} \\
\frac{10}{9} \\
\end{array}$ & 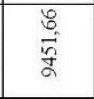 & $\begin{array}{l}8 \\
8 \\
8 \\
8 \\
\end{array}$ & 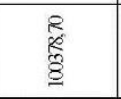 & 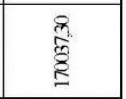 \\
\hline 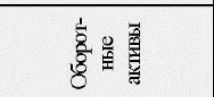 & 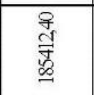 & $\begin{array}{l}\text { हो } \\
\text { हैं }\end{array}$ & 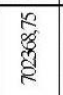 & 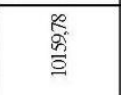 & 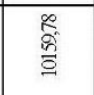 & 这 & 응 & 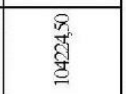 \\
\hline 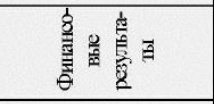 & 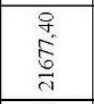 & 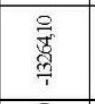 & 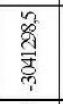 & 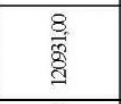 & 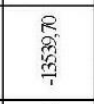 & 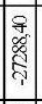 & 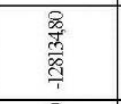 & $\begin{array}{l}8 \\
2 \\
5 \\
1\end{array}$ \\
\hline 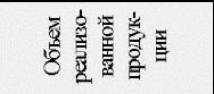 & 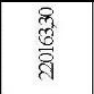 & $\begin{array}{l}8 \\
\stackrel{8}{*} \\
\text { 点 } \\
\end{array}$ & 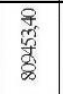 & 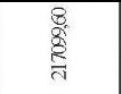 & $\begin{array}{l}8 \\
8 \\
0 \\
0 \\
-10\end{array}$ & 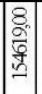 & $\begin{array}{l}8 \\
8 \\
8 \\
\\
\end{array}$ & 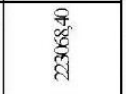 \\
\hline 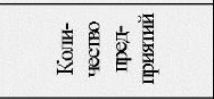 & $\begin{array}{l}8 \\
8 \\
8 \\
0 \\
2 \\
2\end{array}$ & $\begin{array}{l}8 \\
\qquad 1 \\
\infty \\
-1\end{array}$ & 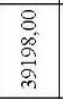 & $\frac{8}{8}$ & $\begin{array}{l}8 \\
5 \\
6\end{array}$ & \begin{tabular}{l}
8 \\
8 \\
$\infty$ \\
\hdashline \\
$i n$
\end{tabular} & $\begin{array}{l}8 \\
\text { 悹 } \\
\text { s. }\end{array}$ & $\begin{array}{l}8 \\
\stackrel{8}{0} \\
\stackrel{0}{\Xi}\end{array}$ \\
\hline 름 & $\begin{array}{l}8 \\
\frac{8}{6} \\
\frac{\sigma}{2} \\
\end{array}$ & $\begin{array}{l}8 \\
\frac{1}{1} \\
\frac{1}{2}\end{array}$ & $\begin{array}{l}8 \\
8 \\
\vdots \\
9\end{array}$ & 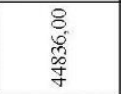 & 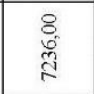 & $\begin{array}{l}8 \\
8 \\
0 \\
8 \\
0 \\
0 \\
0\end{array}$ & हె & $\begin{array}{l}8 \\
8 \\
8 \\
8 \\
8\end{array}$ \\
\hline 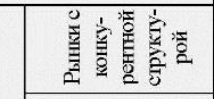 & \begin{tabular}{l}
6 \\
\multirow{6}{*}{}
\end{tabular} & : & $\frac{j}{\stackrel{D}{8}}$ & $\stackrel{8}{\circ}$ & 8 & 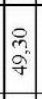 & $\begin{array}{l}\infty \\
\stackrel{\infty}{\circ} \\
\stackrel{8}{0}\end{array}$ & $\begin{array}{l}\delta \\
\stackrel{2}{2}\end{array}$ \\
\hline 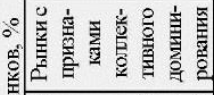 & $\stackrel{m}{\rightarrow}$ & $\begin{array}{l}\text { "q } \\
\stackrel{2}{n}\end{array}$ & $\begin{array}{l}\text { वे } \\
\text { dे }\end{array}$ & 8 & 8 & $\left|\begin{array}{l}2 \\
\infty \\
\infty \\
-1\end{array}\right|$ & $\begin{array}{l}\text { fo } \\
\varrho\end{array}$ & $\begin{array}{l}\infty \\
\infty \\
m\end{array}$ \\
\hline 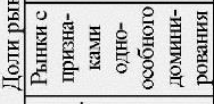 & $\underset{i}{i}$ & $\begin{array}{c}\frac{Z}{f} \\
\tilde{f}\end{array}$ & $\begin{array}{l}8 \\
\text { मुं }\end{array}$ & $\begin{array}{l}2 \\
8 \\
8\end{array}$ & $\begin{array}{l}\text { म } \\
\text { ली }\end{array}$ & $\begin{array}{c}8 \\
8 \\
\text { הi }\end{array}$ & $\begin{array}{l}\text { gे } \\
\text { \& }\end{array}$ & $\begin{array}{l}\infty \\
m^{2} \\
m^{2}\end{array}$ \\
\hline 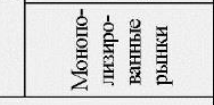 & สิ & $\underset{-}{\mathcal{S}}$ & $\stackrel{\overbrace{}}{-}$ & 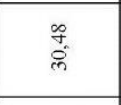 & $\frac{\circ}{8}$ & $\mid \begin{array}{l} \\
O \\
0\end{array}$ & $\begin{array}{l}\infty \\
\stackrel{\infty}{r} \\
\sim\end{array}$ & $\underset{m}{\stackrel{R}{n}}$ \\
\hline 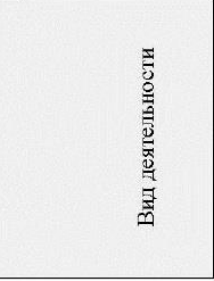 & 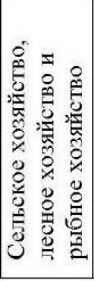 & 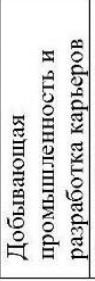 & 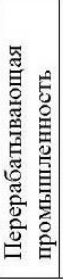 & 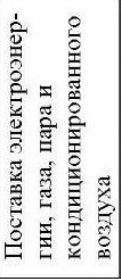 & 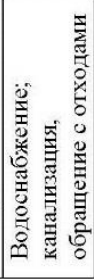 & 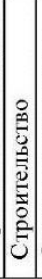 & 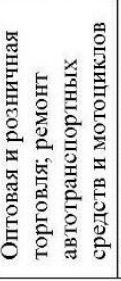 & 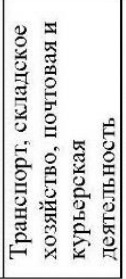 \\
\hline
\end{tabular}




\begin{tabular}{|c|c|c|c|c|c|c|c|c|}
\hline 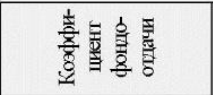 & $\begin{array}{l}8 \\
0 \\
i\end{array}$ & $\begin{array}{l}\infty \\
\infty \\
\infty \\
\infty\end{array}$ & $\stackrel{\infty}{+}$ & $\underset{0}{g}$ & g. & ते & $\stackrel{\circ}{\rightarrow}$ & $\begin{array}{l}\mathscr{h}^{\circ} \\
6\end{array}$ \\
\hline 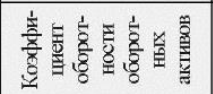 & $\begin{array}{l}\mathscr{\alpha} \\
\mathrm{i}\end{array}$ & ळ. & ले & $\begin{array}{l}f \\
0 \\
0\end{array}$ & $\stackrel{8}{\circ}$ & $\overrightarrow{-}$ & $\overrightarrow{\mathrm{m}}$ & $\hat{m}$ \\
\hline 宊 & ले & $\frac{0}{i}$ & 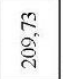 & $\frac{m}{\text { dี }}$ & 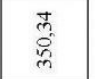 & $\begin{array}{l}\stackrel{8}{2} \\
\stackrel{-}{2}\end{array}$ & \&̊ & $\begin{array}{l}\text { הi } \\
\text { di }\end{array}$ \\
\hline 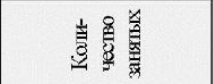 & $\begin{array}{l}\stackrel{0}{8} \\
\stackrel{0}{\circ}\end{array}$ & 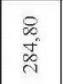 & 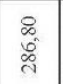 & $\frac{0}{8}$ & $\begin{array}{l}8 \\
80 \\
\text { 要 }\end{array}$ & $\begin{array}{l}\text { D } \\
\text { m } \\
\text { m } \\
\text { m }\end{array}$ & $\frac{\text { নิ }}{\text { dิ }}$ & 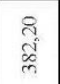 \\
\hline 岁资 & 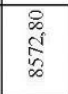 & 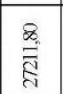 & $\begin{array}{l}8 \\
8 \\
\frac{8}{8}\end{array}$ & \& & $\begin{array}{l}8 \\
\frac{8}{8} \\
\end{array}$ & 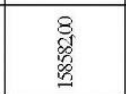 & $\underset{\mathbb{C}}{\stackrel{8}{=}}$ & $\begin{array}{l}8 \\
0 \\
0 \\
0\end{array}$ \\
\hline 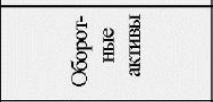 & $\begin{array}{l}\text { P. } \\
\stackrel{8}{\circ} \\
\stackrel{0}{\circ}\end{array}$ & $\begin{array}{l} \\
\frac{d}{w} \\
\frac{d}{m}\end{array}$ & 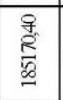 & 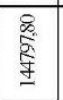 & $\begin{array}{l}\frac{9}{1} \\
\frac{\pi}{7}\end{array}$ & 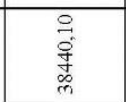 & 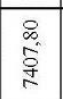 & $\begin{array}{l}R \\
2 \\
2 \\
2\end{array}$ \\
\hline 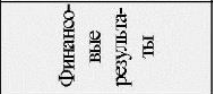 & $\begin{array}{l}8 \\
8 \\
8 \\
6 \\
1\end{array}$ & $\begin{array}{l}8 \\
\frac{6}{1}\end{array}$ & $\begin{array}{l}8 \\
8 \\
8 \\
8 \\
0\end{array}$ & $\begin{array}{l}8 \\
8 \\
8 \\
\frac{8}{1} \\
\end{array}$ & 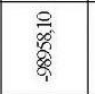 & 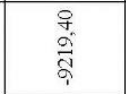 & 啇 & $\frac{9}{6}$ \\
\hline 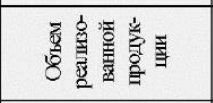 & $\begin{array}{l}8 \\
8 \\
0 \\
0 \\
0 \\
0\end{array}$ & $\begin{array}{l}8 \\
8 \\
8 \\
8 \\
8\end{array}$ & $\begin{array}{l}0 \\
\infty \\
\stackrel{8}{8} \\
8\end{array}$ & $\begin{array}{l}8 \\
\text { I } \\
\frac{f}{8}\end{array}$ & $\begin{array}{l}0 \\
0 \\
0 \\
0 \\
0\end{array}$ & 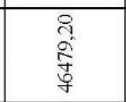 & $\begin{array}{l}\text { R } \\
\circ \\
\stackrel{8}{9} \\
\end{array}$ & $\begin{array}{l}8 \\
8 \\
80 \\
\infty \\
\infty \\
\infty\end{array}$ \\
\hline 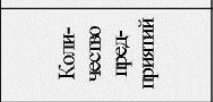 & $\begin{array}{l}8 \\
\hat{\infty} \\
2 \\
i n\end{array}$ & 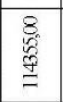 & $\begin{array}{l}8 \\
\infty \\
\infty \\
\infty \\
\infty \\
=\end{array}$ & \begin{tabular}{l}
8 \\
\multirow{8}{0}{} \\
5 \\
5
\end{tabular} & $\begin{array}{l}8 \\
\text { di } \\
\cong \\
\end{array}$ & $\begin{array}{l}8 \\
\text { 妾 } \\
\end{array}$ & \begin{tabular}{|c|}
8 \\
91 \\
6 \\
0 \\
- \\
\end{tabular} & $\begin{array}{l}8 \\
8 \\
8 \\
\infty\end{array}$ \\
\hline 总 & 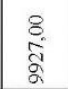 & 离 & ষ্ণ & $\frac{8}{\frac{8}{8}}$ & $\begin{array}{l}8 \\
\text { हो } \\
\text { F }\end{array}$ & 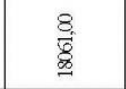 & $\begin{array}{l}8 \\
\text { वृं } \\
\text { త్ }\end{array}$ & 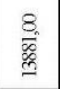 \\
\hline 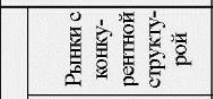 & $\begin{array}{l}\hat{A} \\
\text { of } \\
\stackrel{d}{d}\end{array}$ & $\begin{array}{l}\bar{\sigma} \\
\omega^{2}\end{array}$ & $\stackrel{\text { ले }}{\stackrel{-}{-}}$ & 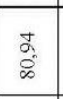 & $\begin{array}{l}\hat{8} \\
\approx \\
\tilde{8}\end{array}$ & $\frac{\stackrel{\rho}{f}}{\stackrel{f}{q}}$ & 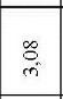 & $\begin{array}{l}\infty \\
\text { oे } \\
\text { ते }\end{array}$ \\
\hline 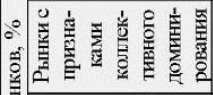 & 㝏 & $\begin{array}{l}\hat{n} \\
\mathrm{n}\end{array}$ & $\stackrel{\infty}{\stackrel{\infty}{2}}$ & हె. & in & $\begin{array}{l}\stackrel{\text { }}{\varrho} \\
\end{array}$ & $\stackrel{\infty}{\rightarrow}$ & $\stackrel{\stackrel{n}{=}}{=}$ \\
\hline 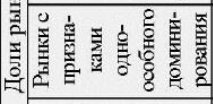 & $\frac{8}{6}$ & $\frac{n}{8}$ & $\begin{array}{l}\infty \\
\infty \\
0 \\
0\end{array}$ & $\stackrel{\circ}{\stackrel{\infty}{\infty}}$ & $\begin{array}{l}\vec{n} \\
\forall\end{array}$ & $\begin{array}{l}\stackrel{n}{1} \\
\text { f }\end{array}$ & $\frac{\pi}{\sigma}$ & $\begin{array}{l}\text { तิ } \\
\text { ถి }\end{array}$ \\
\hline 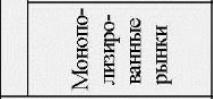 & $\frac{n}{0}$ & $\frac{\infty}{0}$ & $\stackrel{\leftrightarrow}{\approx}$ & $\bar{\sigma}$ & $\begin{array}{l}\mathbb{N} \\
\text { di }\end{array}$ & $\underset{m}{\stackrel{F}{i}}$ & $\begin{array}{l}\vec{\infty} \\
\stackrel{\infty}{n}\end{array}$ & $\begin{array}{l}n \\
n_{\infty} \\
\infty\end{array}$ \\
\hline 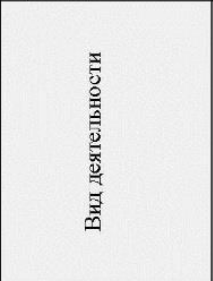 & 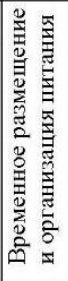 & 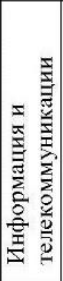 & 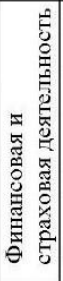 & 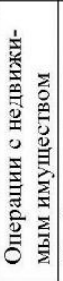 & 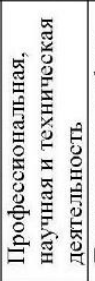 & 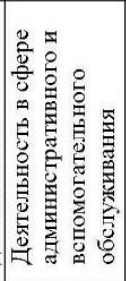 & 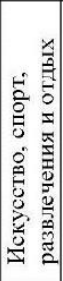 & 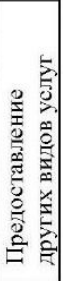 \\
\hline
\end{tabular}




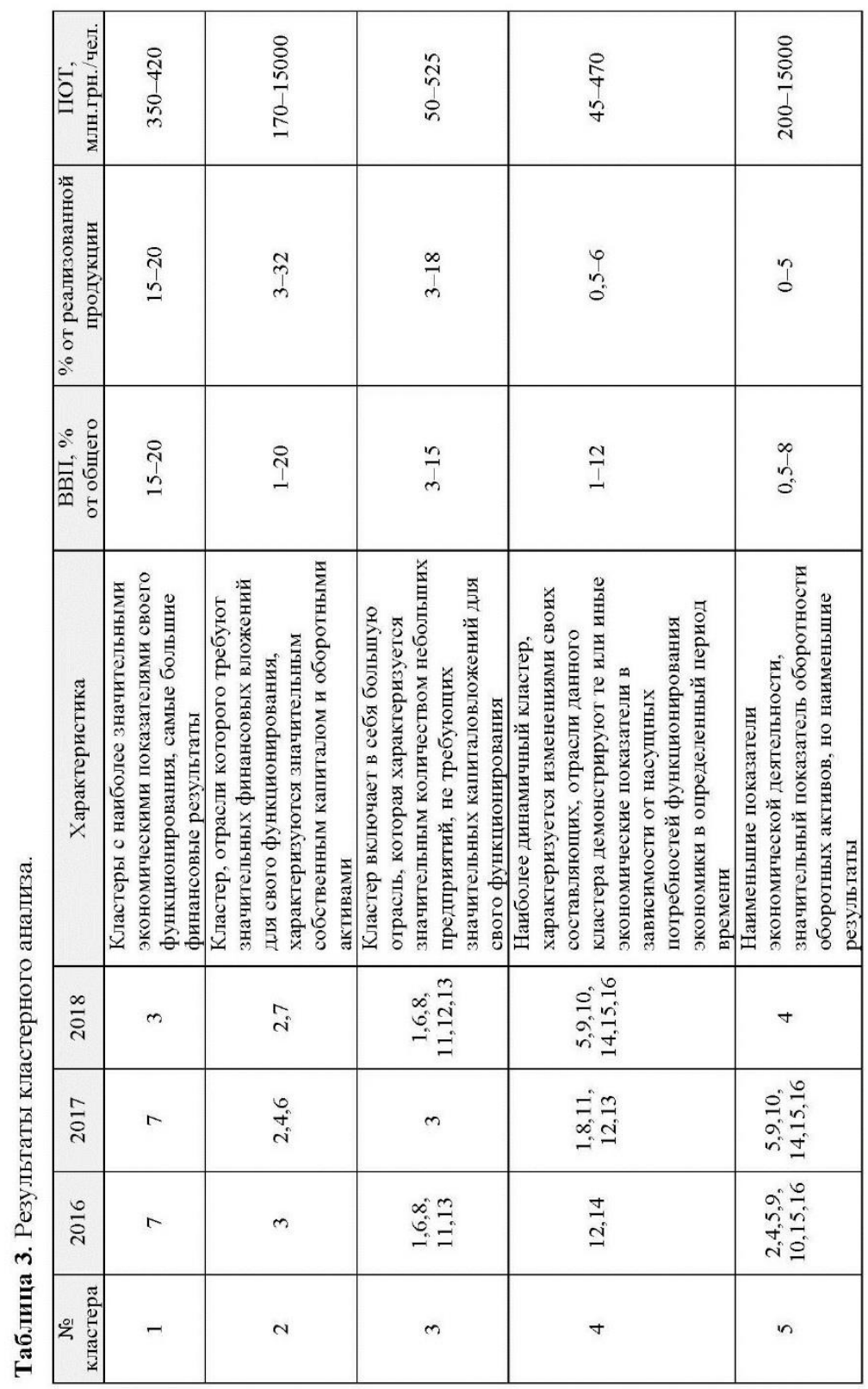


Из таблицы видно, что большое количество отраслей группируются в один кластер и среди всех присутствуют отрасли, явно отличающиеся от всех остальных отраслей. На протяжении всего анализируемого периода можно выделить 7, 3, 2 и 4 отрасли, которым соответствуют «Оптовая и розничная торговля; ремонт автотранспортных средств и мотоциклов (7)», «Перерабатывающая промышленность (3)», «Добывающая промышленность и разработка карьеров (2)» и «Поставка электроэнергии, газа, пара и кондиционированного воздуха (4)». Эти отрасли существенно отличаются от других отраслей, о чем свидетельствуют значительные расстояния между данными отраслями в кластерном анализе и другими отраслями.

Кластерные слияния - это один из способов, который позволяет организовать инновационные процессы всех комплексов, благодаря которому не только отдельные компании вступают в конкурентную борьбу, а несколько компаний, и, как следствие, уменьшается себестоимость продукции в результате совместного технологического сотрудничества. Слияния в кластеры создают особый экономический простор для улучшения условий для свободной торговли, свободного движения капитала и человеческих ресурсов.

Кластеры в экономике - это модель конкурентоспособной и благоприятной для инвестиций экономики, направленной на достижение высокого уровня и качества жизни населения.

Необходимость кластеров заключается в том, что:

- инновационные процессы часто требуют ресурсов и компетенций, которые имеют место вне границ одной компании;

- кластеры - объединение конкуренции и сотрудничества;

- кластеры являются частью более широкой концепции конкурентоспособности;

- кластерные объединения или объединения местных региональных производственных систем способствуют экономическому росту регионов.

Метод кластеризации используют:

- для анализа конкурентоспособности;

- для обеспечения социально-экономического развития;

- для разработки стратегий развития экономики; 
- для обеспечения инновационной политики;

- как основа для большого и малого взаимодействия.

Основной целью кластеризации является повышение внутренней и международной конкурентоспособности его членов путем коммерческого и некоммерческого сотрудничества, исследований и инноваций, образования, обучения и поддержки.

Положительные черты взаимодействия кластера:

- повышение результативности производства;

- эффективная инновационная политика;

- обеспечение доступа к специализированным поставщикам, услугам, квалифицированной рабочей силе, технологическим знаниям;

- большая гибкость и масштабное влияние;

- совместная деятельность;

- коллективная эффективность.

Недостатками кластерного взаимодействия могут быть:

- физическая инфраструктура;

- отсутствие наличного капитала;

- удаленность регионов;

- недостаточное количество рабочей силы, имеющей квалификацию.

Таким образом, разделение отраслей на кластеры дает возможность более детально проанализировать особенности функционирования каждой из отраслей отдельно. Особенности функционирования безусловно влияют на общую конкурентную ситуацию каждого из рынков, полученные кластеры дают возможность понять причины структурных предпосылок функционирования конкуренции на разных рынках, опираясь на экономические показатели, результаты деятельности разных отраслей, выделив их особенности и ключевые характеристики, в том числе такие, которые определяют выбор инструментария платежей и перспективы развития механизма цифровых активов.

Дальнейший анализ должен включать в себя анализ структуры рынков, типа рынков, общей конкурентной ситуации на рынке и процессов, происходящих на нем. Это даст возможность понять особенности его развития, причины функционирования присущей ему структуры и типа, а также даст возможность реагировать на его 
изменения и регулировать его деятельность в случае необходимости.

В процессе развития цифровых технологий происходит изменение существующих постулатов и концепций экономического развития страны. Предыдущий способ производства, построение экономики на промышленно-производственном комплексе отходят в прошлое, на первый план выходят информационно-цифровые активы.

С этим соглашаются и ученые Наджафов 3., Гусейнова А., которые в работе [61, с. 52] выделяют такие основные аспекты развития экономик стран мира: цифровой, сетевой, глобальный, стойкий и инновационный, тем самым подчеркивая новейшие тенденции развития экономик в XXI столетии.

Вышеуказанное предопределяет появление новых явлений и процессов, происходит формирование понятийно-категориального аппарата информационно-цифровой сферы. Так, например, процесс цифровизации рассматривается в широком и узком значениях. В узком понимании под цифровизацией ученые Егоров И. Ю., Рыжкова Ю. А. [62, с. 9] понимают определенное преобразование аналоговых данных и процессов в цифровые, что делает данные и операции с ними значительно более продуктивными, чем при использовании аналоговых технологий.

В более широком понимании цифровизация - это использование данных и цифровых технологий, а также взаимосвязь между ними, что приводит к новым или изменениям существующих видов деятельности, в то время как цифровая трансформация касается экономических и общественных последствий именно цифровизации [62, с. 9].

Цифровые процессы в экономиках стран мира зарождают новое понятие в экономической науке - цифровая экономика. По мнению Кленина О. В. [63, с. 44], под цифровой экономикой понимается «система экономических и социально-культурных отношений, базирующихся на использовании цифровых информационнокоммуникационных технологий, функционирование которой направлено на рост эффективности общественного производства, поддержку стойких темпов роста экономики с целью повышения благосостояния и качества жизни населения». Авторская структура и составляющие цифровой экономики изображены на рисунке 3. 


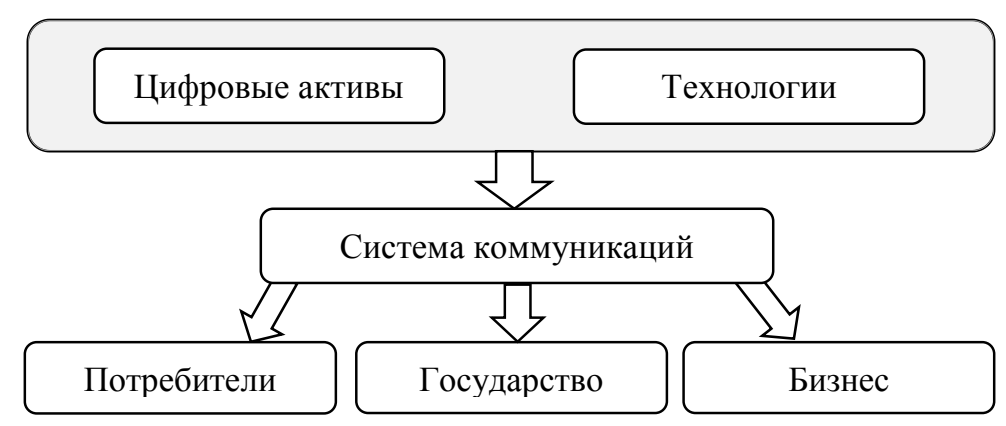

Рисунок 3. Составляющие системы цифровой экономики.

Итак, под цифровой экономикой предлагаем понимать систему цифровых активов и технологий, которые посредством коммуникативной системы взаимодействуют с потребителями, государством и бизнесом для достижения целей стабильного развития страны.

Процессы цифровизации и внедрения цифровых активов в разные сферы социально-экономического развития страны порождают новые явления в экономике и ускоряют уже привычные процессы. Те процессы и методики, которые в прошлом занимали значительный промежуток времени в процессе внедрения цифровых активов, ускоряются, автоматизируются.

Конкуренция на рынках и процессы цифровизации исследуются с помощью индекса цифровой экономики и общества (DESI). Регулярный мониторинг процессов цифровизации экономик стран ЕС позволяет отследить тенденции и спрогнозировать развитие каждой отдельной страны по соответствующему показателю. DESI включает в себя такие показатели:

- связь - развитие рынка широкополосной связи в ЕС;

- человеческий капитал - цифровое включение и навыки;

- использование интернет-услуг;

- интеграция цифровых технологий;

- цифровые общественные услуги;

- ИКТ-сектор ЕС и его научно-исследовательские работы;

- исследования и инновации: ИКТ-проекты в цифровой программе «Горизонт 2020» [64]. 
Указанные показатели в совокупности составляют индекс цифровой экономики и общества, что позволяет понять конкурентоспособность стран ЕС в аспекте цифрового развития, влияние цифровых активов на социально-экономическое развитие (рисунок 4).

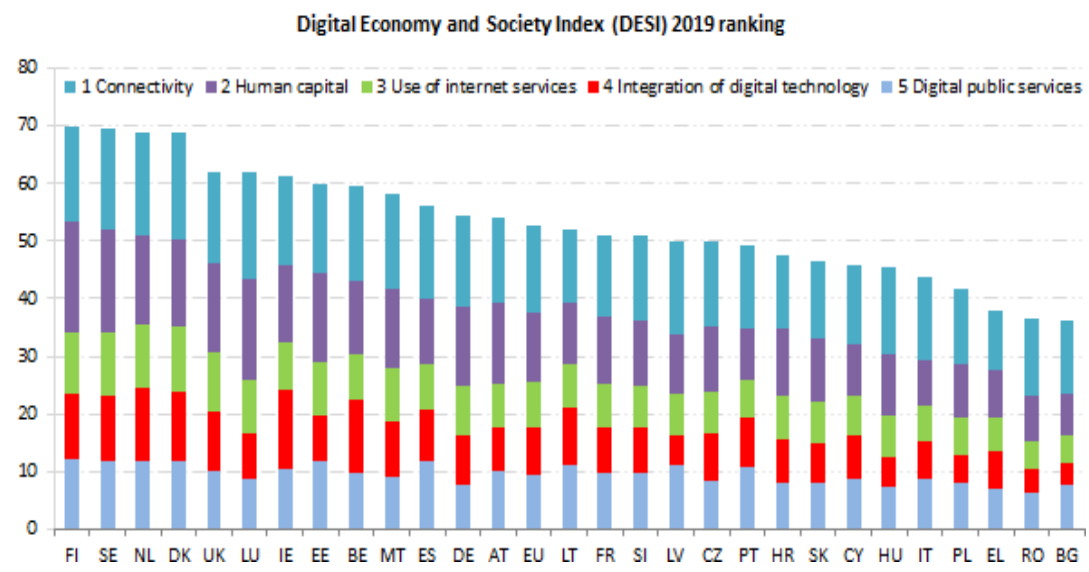

Рисунок 4. Рейтинг стран по составляющим индекса цифровой экономики [64].

Изучение структуры рынка, его типа и экономических процессов, происходящих на нем, связано с изучением состояния конкурентной среды, ее оценкой и исследованием возможностей ограничения или развития конкуренции при внедрении новейших технологий осуществления хозяйственной активности, в частности, связанных с использованием цифровых активов и других информационных продуктов, внедрение которых связано с повышением эффективности использования капиталов в направлении ускорения оборотности средств и осуществления безналичных расчетов, расширения круга источников привлечения ресурсов и др.

Так, к причинам ограничения использования наличных обычно относят высокие расходы их оборота (расходы на производство, 
эмиссию, организацию оборота, а также расходы, связанные с уничтожением старых банкнот). Также влиятельным фактором является анонимный характер наличных денег, стимулирующий рост теневой экономики. Поэтому формируется допущение, что государство должно направить свои регуляторные инструменты на развитие и стимулирование использования безналичных расчетов в розничной торговле. В то же время увеличение доли безналичных расчетов дает возможность обеспечить значительное сокращение срока прохождения платежей, защиту от расхищения, повысит надежность и эффективность расчетов, а также ускорит оборот денежных средств, что даст возможность банкам использовать остатки средств на счетах клиентов для кредитования и осуществления инвестиций в экономику страны.

В качестве средств платежа при осуществлении розничных операций сегодня применяются: наличные (банкноты, монеты), платежные банковские карты (кредитные, дебетовые), чеки, банковские переводы, а также электронные деньги, природа которых близка к частным деньгам. Каждый способ платежа имеет свои особенности, которые позволяют ему занимать определенное положение на розничном платежном рынке. Для удобства анализа предлагается именовать средством платежа все исследуемые средства обмена, включая как средства платежа (деньги), выпущенные в оборот Национальным банком, так и обязательства коммерческих банков и других институтов, которые используются для погашения тех или иных обязательств или проведения операций купли-продажи. Прежде всего необходимо выявить принципиальные отличия упомянутых способов платежа:

- наличные деньги - эмитируются центральным банком в виде банкнот и монет, рассматриваются всеми агентами как законное средство платежа [65];

- депозитные деньги - разные механизмы доступа к банковскому счету. Несмотря на то что таких механизмов существует достаточно много, в рамках данного анализа рассматриваются [66]:

- интернет-банкинг - механизм управления собственным текущим счетом на основе протоколов взаимодействия, определенных банком, и традиционных механизмов клиринга, используемых банком или платежными провайдерами; 
- банковские карты (включая виртуальные) - механизм доступа к специальным счетам, которые открываются банком при использовании протоколов взаимодействия и клиринга, развиваются и поддерживаются международными и национальными платежными системами;

- электронные деньги (e-money) - единицы стоимости, которые сохраняются на электронном устройстве, принимаются как средство платежа другими лицами, помимо лица, которое их выпускает, и являются денежным обязательством этого лица, которое исполняется в наличной или безналичной форме $[67 ; 68]$.

В свою очередь электронные деньги включают в себя три группы продуктов:

- электронные кошельки - перезагружаемые многоцелевые предоплаченные карты, сохраняющие электронную стоимость, используемую для осуществления розничных платежей [69, с. 376]. Важно указать, что электронные кошельки выпускаются в закрыто циркулирующих системах, особенностью которых является то, что в них отсутствует возможность многоразовых переводов одной и той же стоимости между агентами;

- сетевые деньги - предоплаченный продукт, который позволяет использовать средства с помощью специального программного обеспечения. Данное программное обеспечение может размещаться как на компьютере пользователя, так и на удаленном сервере, а транзакции осуществляются с помощью телекоммуникационных сетей (Интернет и т. д.);

- мобильные деньги - предоплаченный продукт, который позволяет использовать средства путем контакта телефона и соответствующего терминала, пополнение средств и обновление необходимого программного обеспечения осуществляется по радиоканалу.

Для того, чтобы определить, какие конкурентные преимущества имеют те или иные платежные инструменты, необходимо систематизировать базовые требования (характеристики), которые предъявляются к средству платежа.

При осуществлении анализа этих требований были учтены специфические факторы, имеющие значение для эмиссионных институтов, коммерческих банков, платежных агентов, продавцов, 
населения и государства. Важно отметить, что упомянутые инструменты рассматриваются только как средство платежа; их свойства в качестве способов накопления и сбережения не рассматриваются.

Среди базовых требований могут быть выделены следующие (таблица 4).

Таблица 4. Базовые требования к средствам платежа (инструментам платежа).

\begin{tabular}{|c|c|}
\hline Баз & гика \\
\hline $\begin{array}{l}\text { Простота } \\
\text { использования }\end{array}$ & $\begin{array}{l}\text { Необходима для массового } \\
\text { средств платежа и избегания трудностей в их } \\
\text { применении. }\end{array}$ \\
\hline $\begin{array}{l}\text { Технологичность } \\
\text { использования }\end{array}$ & 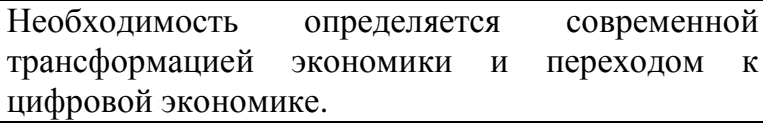 \\
\hline $\begin{array}{l}\text { Устойчивость к } \\
\text { мошенничеству }\end{array}$ & $\begin{array}{l}\text { Средства платежа могут быть использованы } \\
\text { мошенниками при условии их недостаточной } \\
\text { защиты эмитентом, поэтому необходима } \\
\text { разработка механизмов защиты средств платежа. }\end{array}$ \\
\hline мность & $\begin{array}{l}\text { Важное требование, поскольку не все участники } \\
\text { рынка способов платежа } \\
\text { идентифицированы в процтессе } \\
\text { хозяйственных операций. }\end{array}$ \\
\hline аЛЬнОсть & $\begin{array}{lccc}\text { Позволяет } & \text { использовать } & \text { средства платежа в } \\
\text { разных } & \text { хозяйственных } & \text { сферах } & \text { оборота } \\
\text { финансовых } & \text { инструментов. } \\
\text { ограничений } \text { на средьшение } \\
\text { увеличению его распространения. }\end{array}$ \\
\hline Обор & $\begin{array}{l}\text { Способность без специального подтверждения } \\
\text { использоваться в качестве средства платежа между } \\
\text { любыми существующими агентами. }\end{array}$ \\
\hline $\begin{array}{l}\text { Обеспечение } \\
\text { микроплатежей }\end{array}$ & 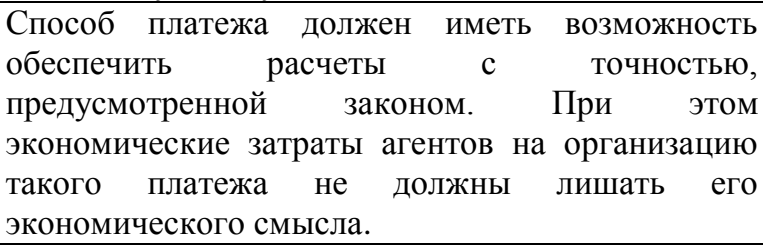 \\
\hline Автономность & Доступность средства платежа без связи с сетью. \\
\hline
\end{tabular}




\begin{tabular}{|c|c|}
\hline Базовые требования & Характеристика \\
\hline Портативность & $\begin{array}{l}\text { Значит, что средства платежа на современном } \\
\text { этапе переходят в другие измерения и имеют } \\
\text { больше разнообразных сфер применения и } \\
\text { видов [69]. }\end{array}$ \\
\hline $\begin{array}{l}\text { Время } \\
\text { использования }\end{array}$ & $\begin{array}{l}\text { Необходимость четко определенного времени и } \\
\text { условий использования средства платежа либо } \\
\text { вневременное использование. }\end{array}$ \\
\hline Ликвидность & $\begin{array}{l}\text { Значит беспроблемный обмен средств платежа на } \\
\text { денежные средства. }\end{array}$ \\
\hline $\begin{array}{l}\text { Экономически } \\
\text { рациональная } \\
\text { стоимость } \\
\text { обслуживания } \\
\text { операций для } \\
\text { участников } \\
\text { экосистемы }\end{array}$ & $\begin{array}{l}\text { Комплексная величина, включающая: } \\
\text { Для покупателя: стоимость владения платежным } \\
\text { средством и размер возможных комиссий при } \\
\text { проведении платежной операции в сопоставлении } \\
\text { с размером такой операции. } \\
\text { Для продавца (merchant): данный показатель } \\
\text { включает стоимость операции (комиссионные } \\
\text { награды платежных систем и финансовых агентов } \\
\text { или издержки, связанные с обработкой налички и } \\
\text { т. д.), а также стоимость преобразования } \\
\text { полученного средства платежа в такую форму, в } \\
\text { которой оно может использоваться в дальнейших } \\
\text { операциях (например, издержки на инкассацию) в } \\
\text { сопоставлении с размером таких операций. } \\
\text { Для банка: издержки связаны с обслуживанием и } \\
\text { процессингом оборота платежных средств [69]. }\end{array}$ \\
\hline $\begin{array}{l}\text { Дополнительное } \\
\text { удобство }\end{array}$ & $\begin{array}{l}\text { Удобство расчетов в сети Интернет. } \\
\text { Возможность планирования, учета и контроля } \\
\text { личных расходов. }\end{array}$ \\
\hline $\begin{array}{l}\text { Эмиссионные } \\
\text { издержки [9] }\end{array}$ & $\begin{array}{lll}\text { Издержки на изготовление } & \text { средства платежа и } \\
\text { расходы, } & \text { связанные } & \text { с обеспечением } \\
\text { функционирования электронных средств платежа. }\end{array}$ \\
\hline $\begin{array}{l}\text { Возможность } \\
\text { получения } \\
\text { эмиссионного } \\
\text { дохода }\end{array}$ & 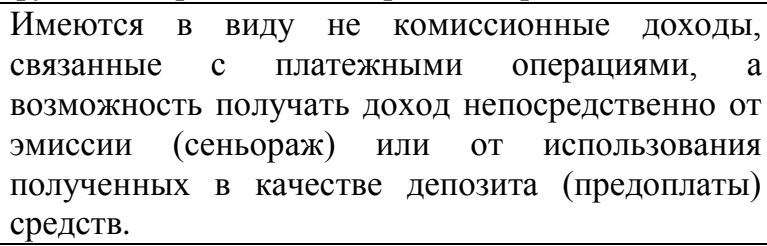 \\
\hline
\end{tabular}


Рассмотрим наиболее популярные средства платежа с точки зрения сформулированных базовых требований. В таблице 5 приведены преимущества и недостатки указанных средств платежа, использующихся сегодня для осуществления розничных платежей.

Таблица 5. Средства платежа и тенденции их развития.

\begin{tabular}{|c|c|c|c|}
\hline Способ & Преимущества & Недостатки & Тенденция \\
\hline $\begin{array}{l}\text { Наличные } \\
\text { деньги }\end{array}$ & $\begin{array}{l}\text { Бесплатный для } \\
\text { населения, } \\
\text { законный способ } \\
\text { платежа. } \\
\text { Простота расчетов } \\
\text { (для небольших } \\
\text { сумм). } \\
\text { Повсеместное } \\
\text { использование. } \\
\text { Возможность } \\
\text { расчетов } \\
\text { «человек-человек» } \\
\text { (далее - Р2Р). } \\
\text { Возможность } \\
\text { анонимных } \\
\text { расчетов. }\end{array}$ & $\begin{array}{l}\text { Существенные } \\
\text { общественные } \\
\text { издержки на налично- } \\
\text { денежный оборот. } \\
\text { Высокий риск потери } \\
\text { в результате } \\
\text { криминальных } \\
\text { действий и стихийных } \\
\text { бедствий. } \\
\text { Трудности при } \\
\text { больших расчетах. } \\
\text { Неприспособленные } \\
\text { для дистанционных } \\
\text { расчетов в сети } \\
\text { Интернет. }\end{array}$ & $\begin{array}{l}\text { Сохраняют } \\
\text { нишу } \\
\text { небольших } \\
\text { платежей. } \\
\text { Постепенное } \\
\text { вытеснение из } \\
\text { сферы средних } \\
\text { и больших } \\
\text { платежей. } \\
\text { Постепенное } \\
\text { возрастание } \\
\text { количества } \\
\text { транзакций. }\end{array}$ \\
\hline $\begin{array}{l}\text { Дебетовые } \\
\text { карты }\end{array}$ & $\begin{array}{l}\text { Удобство исполь- } \\
\text { зования, особенно } \\
\text { для средних по } \\
\text { размеру платежей. } \\
\text { Невысокая стои- } \\
\text { мость транзакции } \\
\text { для бизнеса. } \\
\text { Возможность } \\
\text { дистанционных } \\
\text { платежей. } \\
\text { Снижение рисков } \\
\text { потери всей стои- } \\
\text { мости в результате } \\
\text { криминальных } \\
\text { действий. } \\
\text { Гарантии завер- }\end{array}$ & $\begin{array}{l}\text { Прямо не является } \\
\text { законным способом } \\
\text { платежа. } \\
\text { Наличие издержек } \\
\text { клиента, обусловлен- } \\
\text { ных выпуском и } \\
\text { использованием } \\
\text { карты. } \\
\text { Необходимость } \\
\text { наличия специальной } \\
\text { инфраструктуры. } \\
\text { Сложность расчетов } \\
\text { Р2Р. } \\
\text { Риски криминальных } \\
\text { действий в } \\
\text { электронной среде. }\end{array}$ & $\begin{array}{l}\text { Постепенное } \\
\text { увеличение } \\
\text { доли на рынке } \\
\text { платежей. } \\
\text { Существенный } \\
\text { рост количества } \\
\text { транзакций. } \\
\text { Расширение } \\
\text { охвата по мере } \\
\text { развития } \\
\text { инфраструк- } \\
\text { туры. }\end{array}$ \\
\hline
\end{tabular}




\begin{tabular}{|c|c|c|c|}
\hline Способ & Преимущества & Недостатки & Тенденция \\
\hline & $\begin{array}{l}\text { шения платежа от } \\
\text { банка-эмитента } \\
\text { карты и платежной } \\
\text { системы. }\end{array}$ & & \\
\hline $\begin{array}{l}\text { Кредитные } \\
\text { карты [12] }\end{array}$ & $\begin{array}{l}\text { Удобство } \\
\text { использования. } \\
\text { Наличие } \\
\text { кредитной линии } \\
\text { для клиента. } \\
\text { Стимулирование } \\
\text { покупок. } \\
\text { Возможность } \\
\text { дистанционных } \\
\text { платежей. } \\
\text { Снижение рисков } \\
\text { потери всей } \\
\text { стоимости в } \\
\text { результате } \\
\text { криминальных } \\
\text { действий. }\end{array}$ & $\begin{array}{l}\text { Прямо не является } \\
\text { законным средством } \\
\text { платежа. } \\
\text { Высокая стоимость из } \\
\text { расчета на одну } \\
\text { транзакцию. } \\
\text { Издержки на } \\
\text { содержание карты и } \\
\text { необходимость знаний } \\
\text { по использованию } \\
\text { кредита. } \\
\text { Сложность расчетов } \\
\text { Р2Р. Необходимость } \\
\text { наличия специальной } \\
\text { инфраструктуры. }\end{array}$ & $\begin{array}{l}\text { Постепенный } \\
\text { рост либо } \\
\text { стагнация. } \\
\text { В зависимости } \\
\text { от насыщен- } \\
\text { ности рынка } \\
\text { кредитования и } \\
\text { развития } \\
\text { инфраструк- } \\
\text { туры. } \\
\text { Расширение } \\
\text { охвата по мере } \\
\text { развития } \\
\text { инфраструк- } \\
\text { туры. }\end{array}$ \\
\hline $\begin{array}{l}\text { Предоп- } \\
\text { лаченные } \\
\text { карты } \\
\text { (электрон- } \\
\text { ные } \\
\text { деньги) }\end{array}$ & $\begin{array}{l}\text { Удобство } \\
\text { использования, в } \\
\text { том числе для } \\
\text { микроплатежей. } \\
\text { Возможность } \\
\text { дистанционных } \\
\text { платежей. } \\
\text { Возможность } \\
\text { осуществить } \\
\text { расчеты анонимно. } \\
\text { Возможность } \\
\text { расчетов Р2Р. }\end{array}$ & $\begin{array}{l}\text { Необходимость } \\
\text { наличия специальной } \\
\text { инфраструктуры. } \\
\text { Высокая стоимость } \\
\text { транзакции. } \\
\text { Высокий риск утери в } \\
\text { результате } \\
\text { криминальных } \\
\text { действий и стихий- } \\
\text { ных бедствий. } \\
\text { Ограничения в } \\
\text { отношении органи- } \\
\text { зации анонимных } \\
\text { расчетов к банкам. }\end{array}$ & $\begin{array}{l}\text { Динамичный } \\
\text { рост и } \\
\text { постоянное } \\
\text { увеличение } \\
\text { числа } \\
\text { транзакций. } \\
\text { Ограничение } \\
\text { распростране- } \\
\text { ния сферой } \\
\text { микро- и } \\
\text { средних } \\
\text { платежей. }\end{array}$ \\
\hline $\begin{array}{l}\text { Интернет- } \\
\text { банкинг } \\
\text { (денежные } \\
\text { переводы) }\end{array}$ & $\begin{array}{l}\text { Низкие риски. } \\
\text { Возможность } \\
\text { оплаты больших } \\
\text { сумм. }\end{array}$ & $\begin{array}{l}\text { Сложность процедуры } \\
\text { оплаты. Сложность } \\
\text { процедуры оплаты } \\
\text { при расчетах Р2Р. } \\
\text { Высокая стоимость } \\
\text { транзакции [68]. }\end{array}$ & $\begin{array}{l}\text { Постепенное } \\
\text { дальнейшее } \\
\text { сокращение. } \\
\text { Сохранение } \\
\text { ниши больших } \\
\text { платежей. } \\
\end{array}$ \\
\hline
\end{tabular}


Таким образом, наличные деньги остаются наиболее удобным способом платежа для потребителя благодаря таким ключевым характеристикам, как: бесплатность, повсеместное использование, анонимность расчетов, простота. Именно поэтому они остаются лидирующим инструментом в расчетах не только в Украине, но и во многих странах, где инфраструктура безналичных платежей более развита. Кроме того, результаты анализа помогают объяснить, почему именно банковские (платежные) карты, являясь достаточно технологичным способом платежа, смогут составить конкуренцию наличным расчетам в ближайшем будущем. Такие преимущества, как удобство, безопасность и экономичность использования обусловливают рост объемов использования данного инструмента платежа как в мире в целом, так и в Украине в частности.

Кроме того, анализ базовых требований к средствам платежа позволил выделить основные потребительские факторы роста использования электронных денег. Основным фактором распространения электронных денег является возможность осуществления анонимного платежа (главное преимущество наличных средств). Естественно, стоимость услуги электронных денег по сравнению с другими средствами платежа является значительно выше. При этом потребитель готов доплачивать именно за возможность оставаться анонимным.

Тем не менее дисбалансы и диспропорции, возникающие на финансовом рынке в результате внедрения новейших информационных технологий, являются проявлением и следствием разбалансированности потребностей поддержки целостности, синхронизации протекания и системного единства стадий процесса оборота финансовых ресурсов на конкурентных рынках. Для обобщения характеристик взаимодействия разных составляющих данного процесса с помощью использования метода построения канонических корреляций целесообразным является определение характеристик взаимного влияния и зависимости между наборами (между двумя списками) канонических переменных, к составу которых были отнесены такие параметры групп детерминант, которые по отраслевым сегментам определяют внедрение новейших информационных технологий использования цифровых активов в хозяйственных практиках (рисунок 5). 


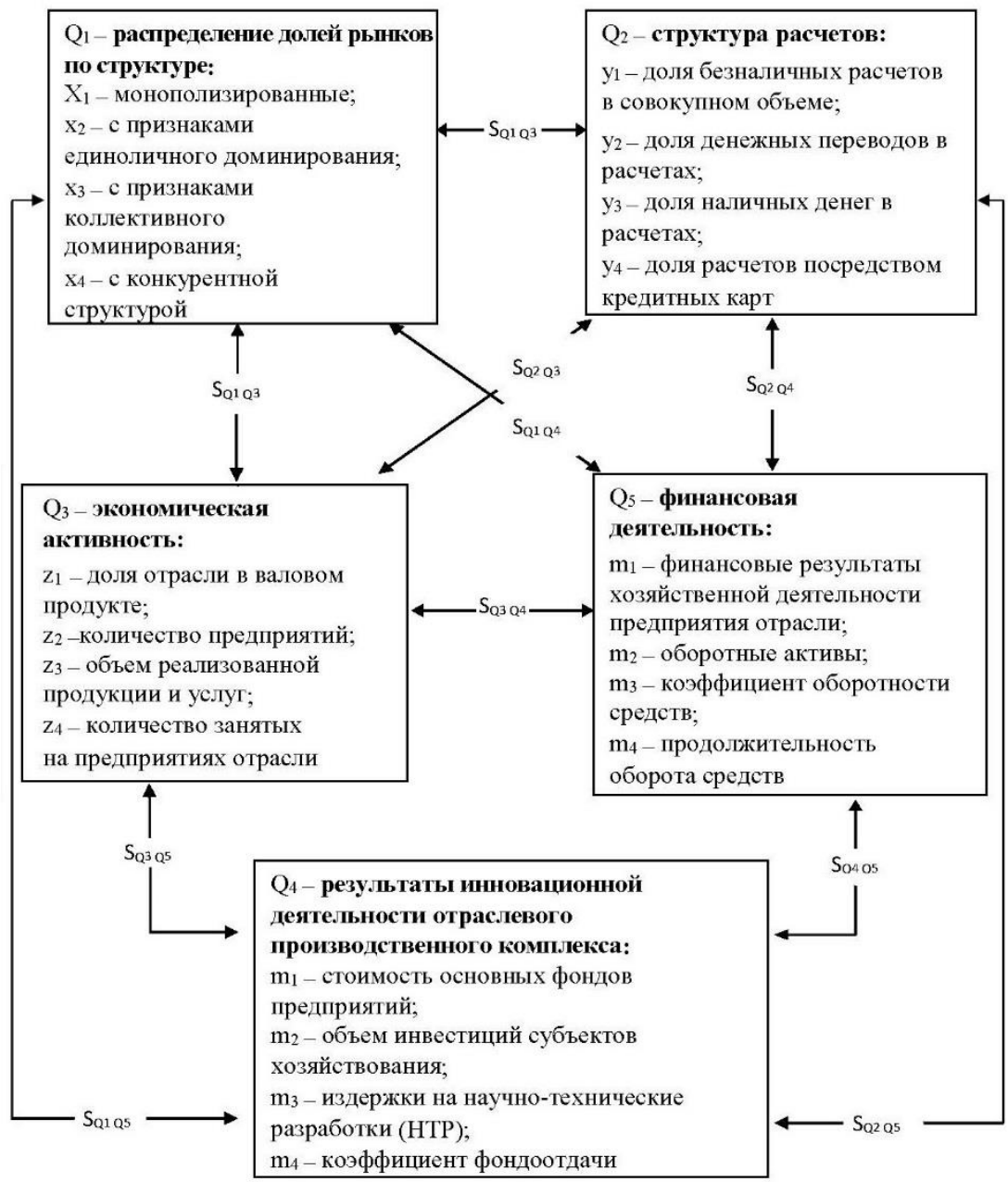

Рисунок 5. Группы детерминант определения влияния конкурентных параметров отраслевых рынков на использование финансовоинформационных технологий безналичных расчетов.

Увеличение доли безналичных расчетов в платежном обороте страны является общемировой тенденцией. Тем не менее дальнейшее увеличение безналичного оборота в Украине должно базироваться на поощрении всех участников этого рынка, а особенно конечного 
потребителя. Анализ способов платежа и их потребительских характеристик позволил выделить преимущества и недостатки каждого из них и противопоставить наличным средствам (как наиболее распространенному среди населения способу расчетов), что в результате позволило выделить конкурентные потребительские характеристики каждого средства платежа. Поэтому для дальнейшего стимулирования безналичных платежей современные и будущие инструменты расчетов должны приобретать такие преимущества наличной формы расчетов: анонимность, бесплатность, распространенность, простота.

Необходимо обозначить, что внедрение цифрового актива требует увеличения уровня доверия со стороны населения к участникам рынка и инфраструктуре безналичных платежей в целом. Следует также принимать во внимание, что доля использования способов безналичных расчетов в общем объеме по торговым операциям будет зависеть от состояния и развития банковской системы и экономики страны, девальвационных и инфляционных ожиданий. Перевод сбережений в безналичную форму при современном состоянии банковской системы может увеличить риски их утери для населения в случае финансовых кризисов. Учитывая это, актуальным направлением дальнейших исследований становится система административного регулирования и стимулирования безналичных расчетов на национальном и глобальном уровнях. 


\section{ВЫВОДЫ}

Исследовано явление социально-экономического развития. Обоснованы особенности социокультурного контекста, формирующие понимание сущности социально-экономического развития.

Определено влияние современных информационных технологий, которые существенно меняют модель и способы ведения бизнеса.

Исследована сущность понятия «цифровой актив» на основе этимологического анализа.

Введена в оборот категория «цифровой актив», учитывающая сущностно-смысловые особенности исследуемого феномена и характеризующаяся четырьмя составляющими: экономической, правовой, информационной, ценностной. Это позволило выделить особенности использования этого понятия, а также уточнить взаимосвязь и взаимозависимость между его составляющими.

Исследована сущность прогнозирования социальноэкономического развития от влияния цифрового актива в условиях антимонополизации экономики.

Определены принципы построения антимонопольного регулирования экономики в условиях цифровизации экономики.

Определены составляющие организационно-методических основ процесса прогнозирования антимонопольного регулирования экономики в условиях цифровизации экономики, а именно: организация деятельности (изучение и анализ реального состояния антимонопольного регулирования; определение стратегических и тактических целей); организация условий (нормативно-правовое, научно-информационное, кадровое, технологическое, материальнотехническое, финансовое обеспечения); организация мониторинга антимонопольного регулирования; диагностика (готовность к осуществлению антимонопольного регулирования, владение методикой антимонопольного регулирования); подготовка к осуществлению антимонопольного регулирования; подготовка к изучению результативности антимонопольного регулирования; мониторинг результативности прогноза; адаптация результатов и изменение целей антимонопольного регулирования. 
Проанализированы отрасли и особенности их функционирования с помощью кластерного анализа, что позволит сформировать модель конкурентоспособной и благоприятной для инвестиций экономики, направленной на достижение высокого уровня и качества жизни населения.

Обосновано, что дисбалансы и диспропорции, возникающие на финансовом рынке в результате внедрения новейших информационных технологий, являются проявлением и следствием разбалансированности потребностей поддержки целостности, синхронизации и системного единства стадий процесса оборота финансовых ресурсов на конкурентных рынках. Для обобщения характеристик взаимодействия разных составляющих данного процесса с помощью использования метода построения канонических корреляций определены характеристики взаимного влияния и зависимости между наборами (между двумя списками) канонических переменных, в состав которых были включены такие параметры групп детерминант, которые по отраслевым сегментам определяют внедрение новейших информационных технологий использования цифровых активов в хозяйственных практика. 


\section{ЛИТЕРАТУРА}

1. Департамент економічної стратегії та макроекономічного прогнозування. Економічний розвиток у розрізі регіонів України. Міністерство розвитку економіки, торгівлі та сільського господарства України: веб-сайт. URL: https://www.me.gov.ua (Last accessed: 14.01.2020).

2. The treaty on the functioning of the European Union. Official Journal of the European Union. 2012. Vol.55. URL: http://data.europa.eu/eli/treaty/tfeu_2012/oj doi:10.3000/1977091X.C_2012.326.eng (Last accessed: 14.01.2020).

3. European Commission. Investment for jobs and growth. Promoting development and good governance in EU regions and cities. European Commission: website. URL: http://ec.europa.eu (Last accessed: 17.01.2020).

4. European Commission. Europe 2020. Priorities. European Commission: website. URL: http://ec.europa.eu (Last accessed: 18.01.2020).

5. Commission of the European Communities. Communication from the Commission to the Council and the European Parliament. European Environment Agency: website. URL: https://www.eea.europa.eu (Last accessed: 18.01.2020).

6. European Commission. Connecting Europe Facility. European Commission: website. URL: https://ec.europa.eu (Last accessed: 18.01.2020).

7. Atlantic Council and CEEP. Completing Europe - From the North-South Corridor to Energy, Transportation, and Telecommunications Union. Atlantic Council: website. URL: https://www.atlanticcouncil.org (Last accessed: 20.01.2020).

8. European Commission. Eurostat. European Commission: website. URL: http://ec.europa.eu (Last accessed: 20.01.2020).

9. Аверьянов М., Евтушенко С., Кочетова Е. Цифровая экономика: новые активы. itWeek: веб-сайт. URL: https://www.itweek.ru (дата обращения: 02.02.2020).

10.Арянова Т. Какое будущее ждет цифровые активы. Ihodl Russia: веб-сайт. URL: https://ru.ihodl.com (дата обращения: 02.02.2020). 
11.Сапожков О., Крючкова Е. Цифровые активы двинулись вспять. Коммерсантъ. 2018. №221. URL: https://www.kommersant.ru (дата обращения: 05.02.2020).

12.Buntinx J. P. Digital assets vs cryptocurrencies. The Merkle: website. URL: https://themerkle.com (Last accessed: 06.02.2020).

13.Fiduciary Access to Digital Assets and Digital Accounts: Act of 12.08.2014 // Delaware Code Online. URL: http://delcode.delaware.gov/title12/c050/index.shtml (Last accessed: 06.02.2020).

14.Gray G. H. New York's Fiduciary Access to Digital Assets Act. Gfrllp: web portal. Last updated: 20.10.2016. URL: http://gfrllp.com/Portals/gfrllp/Documents/NYS-Fiduciary-Access-toDigital-Assets-Gray-Feldman-LLP.pdf (Last accessed: 06.02.2020).

15.Harbinja E. Legal aspects of transmission of digital assets on death: Doctoral dissertation, University of Strathclyde. Glasgow, 2017. URL: http://digitool.lib.strath.ac.uk/R/?func=dbin-jumpfull\&object_id=28644 (Last accessed: 07.02.2020).

16.Kud A., Pypenko I. Social and economic foundation of the implementation of blockchain-based systems of digital assets in developing countries. International Journal of Education and Science. 2018. Vol. 1. No. 3-4. P. 30. doi:10.26697/ijes.2018.3-4.30

17.Have you made a plan for your digital assets? Osterman Law Firm: website. URL: https://www.ostermanlaw.com (Last accessed: 07.02.2020).

18. Walker M. D. The new uniform digital assets law: estate planning and administration in the information age. Real Property, Trust and Estate Law Journal. 2017. № 52 (1). P. 52-78. URL: https://www.americanbar.org/content/dam/aba/publications/real_propert y_trust_and_estate_law_journal/v52/01/rpte-journal-2017-52-1-articlenew-uniform-digital-assets-law-estate-planning-and-administration-ininformation-age\%20.authcheckdam.pdf (Last accessed: 10.02.2020).

19.Эфириум новости. В чем причина краха ETH? BitStat: вебсайт. URL: http://bitstat.top (дата обращения: 10.02.2020).

20.Захарова Н. Глава Ripple: “Криптовалюты - это не валюты, а цифровые активы”. BitGit: веб-сайт. URL: https://bitgid.com (дата обращения: 11.02.2020). 
21.Цегоев В. История одной монеты: как биткоин повлиял на мировой финансовый рынок за десять лет своего существования. $R T$ на русском: веб-сайт. URL: https://russian.rt.com (дата обращения: 12.02.2020).

22.Великая Е. Обложат ли виртуальные активы реальными налогами? Delo: веб-портал. Дата обновления: 07.12.2018. URL: https://delo.ua/econonomyandpoliticsinukraine/oblozhat-li-virtualnyeaktivy-realnymi-nalogami-348461 (дата обращения: 12.02.2020).

23.Про внесення змін до Податкового кодексу України щодо оподаткування операцій з віртуальними активами в Україні: проект Закону від 27.09.2018 № 9083-1 // Інформ.-правова система “ЛігаЗакон"/ВР України.

URL: http://search.ligazakon.ua/__doc2.nsf/link1/JH70B1AA.html (дата звернення: 15.02.2020).

24.Lenz D. M. Afterlife on the cloud: creating a heavenly plan for electronic assets. Bar Journal. 2012. URL: https://www.sssblaw.com/media/1104/afterlife_on_the_cloud.pdf (Last accessed: 15.02.2020).

25.Owens J. Blockchain 101 for Governments. Vienna: Wilton Park. URL: https://www.wiltonpark.org.uk/wpcontent/uploads/WP1566-Blockchain-101-for-Governments.pdf (Last accessed: 15.02.2020).

26.Latham \& Watkins discusses SEC official's analysis of digital assets as securities/Wink S. P. and others. The CLS Blue Sky Blog: web portal. Last updated: 02.07.2018. URL: http://clsbluesky.law.columbia.edu/2018/07/02/latham-watkinsdiscusses-sec-officials-analysis-of-digital-assets-as-securities/\#_edn4 (Last accessed: 15.02.2020).

27.ДСТУ 3966-2000. Термінологія. Засади і правила розроблення стандартів на терміни та визначення понять. [Чинний від 01.01.2001]. Київ: Держстандарт України, 2000. 36 с.

28.Научно-технический энциклопедический словарь. Академик: веб-сайт. URL: https://dic.academic.ru (дата обращения: 16.02.2020).

29.Ефремова Т. Ф. Новый словарь русского языка. 2-е изд. Москва: Русский язык, 2001. 1084 с. 
30.Финансы. Толковый словарь/общ. ред. И. М. Осадчая. 2-е изд. Москва: “Инфра-М”, издательство “Весь Мир”, 2000.

31.Энциклопедический словарь: в 86 т./под ред. И. Е. Андреевского и др. URL: www.vehi.net/brokgauz/ (дата обращения: 16.02.2020).

32.Райзберг Б. А., Лозовский Л. Ш., Стародубцева Е. Б. Современный экономический словарь. 6-е изд., перераб. и доп. Москва: Инфра-М, 2011. 512 с.

33.Ожегов С. И. Толковый словарь русского языка. Москва: Оникс: Biblio, 2010. 736 c.

34.Великий тлумачний словник сучасної української мови (з дод. і допов.)/уклад. і голов. ред. В. Т. Бусел. Київ; Ірпінь: ВТФ "Перун", 2005. 1728 с.

35.Краткий словарь по кибернетике. Chernykh: веб-сайт. URL: http://chernykh.net (дата обращения: 16.02.2020).

36.Про затвердження Порядку подання та обігу електронних документів державному реєстратору юридичних осіб та фізичних осіб-підприємців: Наказ від 09.02.2016 № 359/5 // База даних “Законодавство України”/M-во юстиції України. URL: https://zakon.rada.gov.ua/laws/show/z0200-16 (дата звернення: 17.02.2020).

37.Про затвердження Порядку проведення електронних аукціонів з розподілення пропускної спроможності міждержавних електричних мереж: Постанова від 28.03.2017 № 426 // База даних “Законодавство України”/Нац. Коміс. України. URL: https://zakon.rada.gov.ua/laws/show/v0426874-17/ed20170328\#n63 (дата звернення: 17.02.2020).

38.Толковый словарь русского языка: в 4 т./под ред. Д. Н. Ушакова. Москва: Терра-Книжный клуб, 2007. Т. 4. 752 с.

39.Додонов В. Н., Ермаков В. Д., Крылова М. А. Большой юридический словарь. Москва: Инфра-М, 2009. 864 с.

40.Матузов Н. И., Малько А. В. Теория государства и права: учебн. 4-е изд., испр. и доп. Москва: Издательский дом "Дело" РаНХиГС, 2015. $528 \mathrm{c}$. 
41.Про Національну програму інформатизації: Закон від 01.09.2016 № 74/98-ВР // База даних “Законодавство України”/ВР України. $\quad U R L: \quad$ https://zakon.rada.gov.ua/cgibin/laws/main.cgi?nreg=74\%2F98-\%E2\%F0 (дата звернення: 17.02.2020).

42.Об информации, информатизации и защите информации: Закон Республики Беларусь от 10.11.2008 № 455-3 // База данных “Белтим СБ”. URL: https://www.beltim.by/wiki/documents/zakonrespubliki-belarus-ob-informatsii-informatizatsii/ (дата обращения: 17.02.2020).

43.Енциклопедія сучасної України: у 20 т. URL: http://esu.com.ua/search_articles.php?id=12472 (дата звернення: 18.02.2020).

44.Долинко В. И. Все об информационно-коммуникационных технологиях и системах связи: учебн. пособ. Москва: Litres, 2018. $59 \mathrm{c}$.

45.Финансовый словарь. Академик: веб-сайт. URL: https://dic.academic.ru/dic.nsf/fin_enc/23466 (дата обращения: 18.02.2020).

46.Поляков В. П., Косарев В. П. Информатика для экономистов: учебн. Москва: Издательство Юрайт, 2014. 524 с.

47.Шуремов Е. Л. Информационные ресурсы: классификация, источники, поставщики. Коротко о главном. Москва: Издательские решения, 2017. 150 с.

48.Прокопенко А. Н. О содержании понятия информационные ресурсы в праве. Бизнес в законе. 2010. № 1 . C. $157-160$.

49.Информационные ресурсы развития Российской Федерации: Правовые проблемы/отв. ред. И. Л. Бачило. Москва: Наука, 2003. 402 с.

50.Финансово-инвестиционный толковый словарь. Академик: веб-сайт. URL: https://dic.academic.ru (дата обращения: 18.02.2020).

51.Финансовый словарь. Академик: веб-сайт. URL: https://dic.academic.ru/dic.nsf/fin_enc/26068 (дата обращения: 18.02.2020). 
52.Уолпорт М. Технология распределенного реестра: за рамками блокчейн. Plus: веб-сайт. URL: https://www.plusworld.ru (дата обращения: 19.02.2020).

53.Применение технологии распределенного реестра для построения защищенного документооборота/Заворина Л. Д. и др. Известия Тульского государственного университета. 2018. Вып. 10. С. 3-7.

54.Савельев А. Юридическая дефиниция блокчейна. Zakon: веб-портал. Дата обновления: 30.10.2017. URL: https://zakon.ru/blog/2017/10/30/chast_2_yuridicheskaya_definiciya_bl okchejna_a_tochnee_-_raspredelennogo_reestra_dannyh (дата обращения: 19.02.2020).

55.Бизнес. Толковый словарь/общ. ред. И. М. Осадчая. Москва: “Инфра-М”, издательство “Весь Мир”, 1998.

56.Энциклопедический словарь. Tolkslovar: веб-сайт. URL: http://tolkslovar.ru (дата обращения: 19.02.2020).

57.Грабовецький Б. С. Планування та економічне прогнозування : навчальний посібник. Вінниця : ВНТУ, 2013. 66 с.

58.Стельмащук А. М. Державне регулювання економіки. Тернопіль: ТАНГ, 2000. 315 с.

59.Швайка Л. А. Державне регулювання економіки. Київ: Знання, 2006. 435 с.

60.Дикань Н. В., Борисенко I. I. Менеджмент: навч. посіб. для студентів, аспірантів, викладачів ВНЗ. Київ, 2008. 389 с.

61.Наджафов 3., Гусейнова А. Новая экономика XXI века или цифровизация экономики? Побудова інформаційного суспільства: ресурси $i$ технологї: матеріали XVIII Міжнародної наук.-практ. конф., 19-20 верес. 2019 р. Київ: УкрIНTЕI, 2019. С. 52-59.

62.Єгоров I., Рижкова Ю. Соціально-економічні аспекти процесів цифровізації: інструменти дослідження у країнах ОЕСР. Побудова інформаційного суспільства: ресурси $i$ технологї: матеріали XVIII Міжнародної наук.-практ. конф., 19-20 верес. 2019 р. Київ: УкрIНТЕI, 2019. С. 9-12.

63.Кленін О.В.основні тренди цифрової трансформації держави та бізнесу. Побудова інформаційного суспільства: ресурси i технології: матеріали XVIII Міжнародної наук.-практ. конф., 19-20 верес. 2019 р. Київ: УкрIНTЕI, 2019. С. 44-47. 
64.The digital economy and society index (DESI). European Commission: website. URL: https://ec.europa.eu (Last accessed: 15.02.2020).

65.World payments report 2014: Report of Capgemini and The Royal Bank of Scotland. Capgemini: website. URL: https://www.capgemini.com (Last accessed: 15.02.2020).

66.Ринок карткових платежів України: міжнародний досвід та національне регулювання. Аналітичний звіт. Київ: АДЕФ-Україна, 2012. $60 \mathrm{c}$.

67.Бублик Є. О. Обмеження готівкових розрахунків в Україні: проблеми та перспективи. Економіка і прогнозування. 2013. № 2. C. 32-42.

68.Лист 02/03-2014 НБУ від 15.04.2014 [додаток 1]: Українська міжбанківська асоціація членів платіжних систем. 2014. URL:

http://ema.com.ua/wpcontent/uploads/2014/05/strategy_development_ improvement_payments.pdf (дата звернення: 17.02.2020).

69.Кочергин Д. А. Электронные деньги. Санкт-Петербург: Маркет ДС, 2011. 424 с.

70.Ткачук А. В. Перспективы распространения безналичных розничных платежем. Деньги и кредит. 2012. № 7. С. 24-32.

71.Річний звіт Національного банку України за 2013 рік: затв. рішенням Ради Національного Банку України від 24.04.2014 p. № 13. URL: http://www.bank.gov.ua/doccatalog/document?id=8253030 (дата звернення: 17.02.2020). 
Заметки 


\section{Прогнозування впливу цифрових активів на соціально-економічний розвиток підприємства Методичний посібник (Рос. мовою)}

\section{КУДЬ Александр Александрович \\ МАЩЕНКО Марина Анатоліївна ПИПЕНКО Ірина Сергї̈вна СОБОЛЕВА Ірина Володимирівна \\ ISBN 978-617-7089-10-9 \\ DOI 10.26697/9786177089109.2020}

Видасться в авторській редакції

Відповідальний випусковий: Ю. Б. Мельник

Комп'ютерне складання та верстання: Я. Ю. Свячена

Формат 80x64 $\frac{1}{6}$

Гарн. «Times». Папір для мн. ап. Друк цифровий.

Ум. друк. арк. 4,65. Зам. № 1-28.

Тираж 300 пр.

Харківський національний економічний університет імені С. Кузнеця Україна, 61166, м. Харків, пр. Науки, 9-а

Харківська обласна громадська організація “Культура Здоров'я"

Україна, 61105, м. Харків, пров. Забайкальський, 6/6. http://publisher.culturehealth.org; тел./факс: (057)775-75-23.

Emails: CultureHealth@ukr.net; KOSOCH@gmail.com;

Свідоцтво про державну реєстрацію видавництва ДК № 4387 від 10.08.2012 